Cl

$3: 46$

North Carolinal State Etararyolos

N. C Raleigh

\title{
THE SHRUBS AND \\ WOODY VINES OF \\ NORTH CAROLINA
}

BULLETIN 46

NORTH CAROLINA

DEPARTMENT OF CONSERVATION AND DEVELOPMENT

R. BRUCE ETHERIDGE, DiRECTOR

RALEIGH, 1945 



\section{THE SHRUBS AND \\ WOODY VINES \\ OF \\ NORTH CAROLINA}

A REPRINT FROM

GEOLOGICAL AND NATURAL HISTORY SURVEY

PART III-BOTANY

TREES, SHRUBS AND WOODY VINES

By Rev. M. A. Curtis, D.D.

1860

-

BULLETIN 46

DEPARTMENT OF

CONSERVATION AND DEVELOPMENT

DIVISION OF

FORESTRY AND PARKS

W. K. Beichler, State Forester 


\section{NORTH CAROLINA \\ BOARD OF CONSERYATION AND DEVELOPMENT*}

Governor R. GREGG CherRY, Chairman

\section{FOR A TWO YEAR TERM}

JOSH L. HORNE Rocky Mount

W. J. DAMTOFT Canton W. ROY HAMPTON Plymouth A. H. GUION Charlotte CHARLES S. AlleN Durham

FOR A FOUR YEAR TERM

K. Clyde Council Wananish

J. WILBUR BUNN Raleigh DR. J. D. RUDISILL** Lenoir A. K. WINGET Albemarle Percy B. Ferebee Andrews

FOR A SIX YEAR TERM

OSCAR P. BREECE Fayetteville

D. M. STAFFORD Greensboro

R. FlOYd CROUSE Sparta Miles J. SMITH Salisbury J. R. WOLLETT Littleton

R. Bruce Etheridge, Director

*Appointed by Governor Cherry, June 2nd, 1945.

**Died July 28, 1945.

R. W. Proctor, Marion, appointed August 1, 1945, to succeed him. 


\section{FOREWORD}

Dr. Joseph Austin Holmes, in his paper "Historical Notes Concerning the North Carolina Geological Surveys, published in The Journal of the Elisha Mitchell Scientific Society, 1889, states that there were three North Carolina State surveys that have been called geological surveys: (1) the "Geological and Mineralogical Survey," conducted by Professors Denison Olmsted and Elisha Mitchell (1824-'28), termed the Olmsted-Mitchell survey; (2) the "Geological, Mineralogical, Botanical and Agricultural Survey, "prosecuted under Professor Ebenezer Emmons (1852-'61 or '64), called the Emmons Survey; and (3) the "Geological, Mineralogical, Botanical and Agricultural Survey, "prosecuted under Professor W. C. Kerr (1866-'85), termed the Kerr survey. The last mentioned of these may be considered in part a continuation of the second." The fourth "geological Survey" began in 1891 and was in charge of Dr. Holmes himself, as State Geologist. It continued until 1905 when it was reorganized by the General Assembly into the fifth survey, legally termed the North Carolina Geological and Economic Survey. Dr. Joseph Hyde Pratt, an expert in what might be called the Holmes Survey, was appointed State Geologist. He retained direction of that survey until 1924 when its offices were removed from Chapel Hill to the State Capitol. Up until this time all of the men in charge of these surveys were professors at the University and their offices were in a university building.

The General Assembly of 1925, in creating the Department of Conservation and Development, gave as its first object "To take over the powers and duties exercised by the State Geological and Economic Survey, the State Geological Board and the State Geologist." Thus, reports of these previous surveys became the inheritance of the present Department of Conservation and Development and it becomes the privilege of this Department to make available to the inquiring public such useful information collected by these surveys as may be of interest and value to the people of the State.

The second, or Emmons Survey, called for "a survey of every county to ascertain, among other things, the character and value of its botanical productions; the character and value of its timber; and all other facts connected with the subjects of geology and mineralogy, botany, and agriculture which may tend to a full development of the resources of the State." An annual appropriation of $\$ 5,000$ was made for its support. The man 
employed by Dr. Emmons to carry out the "botanical" survey was one who was already familiar with the "botanical production" of every part of North Carolina, the Rev. M. A. Curtis, rector of the Episcopal Church at Hillsboro, N. C. His pecuniary compensation was $\$ 500$ per annum for the years 1859 to 1865 .

Moses Ashley Curtis was born May 11, 1808, at Stockbridge, Mass., the son of the Rev. Jared Curtis. His mother was Thankful Ashley, daughter of Gen. Moses Ashley. A graduate of Williams College (1827) he came to Wilmington in 1830 as tutor in the family of Governor Dudley. In December 1834 he married Mary DeRosset of Wilmington and a year later was ordained a minister in the Episcopal Church. After three years' missionary work out from Lincolnton, N. C. and two years teaching in Raleigh, he spent a year in our mountains on account of his health. Then after a short period of mission work at Washington, N. C. he removed early in 1841 to Hillsboro where he lived until his death in 1872, except for the years 1847-56 when he took the pastorate at Society Hill, S. C. Practically his only publication, outside of articles in the scientific press, were "The Woody Plants of North Carolina," (1860) of which this "Shrubs and Vines of North Carolina" was the latter part; the first part dealt with the "Trees of North Carolina." His studies, however, extended to all plant life and greatly extended our knowledge of the fungi, lichens, liverworts, etc. Donald C. Peattie, in summarizing his biological sketch of Dr. Curtis, in the Dictionary of American Biography, says: "Like the evolution controversy the great military conflict (the War between the States) seems scarcely to have touched his tranquil nature, given as it was to religion and science which for him transcended all animosities," and Thomas F. Wood, in his paper on Dr. Curtis, read before the Elisha Mitchell Scientific Society May 22, 1885, quoted this very pertinent verse: "For him the earth was crammed with Heaven, and every common bush afire with God."

In recommending the publication of this old report, it is realized that changes have taken place in the classification and scientific nomenclature* of our native plants but the common names have changed very little. Since no recent book on North Carolina shrubs can now be had, it seems wise to make available this painstaking and popularly written report until something else is available. "Common Forest Trees of North Carolina," published by this Department, and the much more adequate books, "Trees of the Southeastern States," by Coker and Totten, and "Trees of the South," by Charlotte Hilton Green, already supply information on the trees of the state. There has for some time been under preparation a book on the shrubs of the state 
by members of the State University staff. It is felt that this present edition of this report will fill in the period until such a new and up-to-date book becomes available.

The reader is herewith assured that no changes have been made in the text of this list; it is just as Dr. Curtis wrote it and the State published it eighty-five years ago; a report that inspired the writer of the above lines to study the woody plants of his adopted State.

JoHn Simcox Holmes, Associate Forester.

*Nomenclature throughout follows "Chapman's Flora of the Southeastern States," first edition. 



\section{INDEX}

Alder

Alder, Dwarf

27 (Forsteronia)

Alder, White

25 French Mulberry _.........

20 Fringe Tree

(Andromeda)

Arbor Vitae _._._._._._-_

17 Gallberry

28 Goose Berry

12 Grapes

Arrow Wood

(Ascyrum)

(Astragene)

Azalea

28 Green Briar _._._._._._.

38 Groundsel _...

18 Hardhack

Bamboo _-

Barberry

Bearberry

Bear Grass _._._._._-_._

Bear Oak

Bittersweet

Blackberry

Bladder Nut

Blueberry

Box

(Buckleya)

Buckthorn, Carolina -.---

Buffalo Tree

Bullace

Burning Bush

Bursting Heart

Bush Honeysuckle

Button Bush

Calico Bush

Candle-berry -

Cane

(Cassandra)

China Root _.._-_._-_.

Chinquapin

Choke Berry

(Cornus)

(Cocculus)

Coral Berry

Cornel

Cranberry

Creeper, Virginia

Cross Vine

Currant

Dahoon Holly _.......

(Darbya)

(Decumaria)

Deer Berry

Devil's Shoe Strings

Dew Berr

Dogwood, Swamp

Dutchman's Pipe

Eglantine

Elder

Elder, Marsh

Fern, Sweet

Fetter Bush

34 Hazel Nut _._._-_-_-_-_-

6 Hazel, Witch

8 Haw, Black

16 Haw, Scarlet _.

1 Hawthorn -

37 Heath, False _.........

10 Hemlock _...........

27 Hobble Bush

8 Honeysuckle _._-_-_._-

26 Hop Tree _._._._._.

25

14 Huckleberry, He

16 (Hudsonia) _...--

32 Hydrangea _..._._._._._-

22 Hypericum _..._.........

22 Ilex

22 Indigo Bush _..._._._._.

26 Inkberry _...

19 (Itea)

26 Ivy -...-...-_.

28 Jessamine _._._-_._-_._-

18 Laurel

34 Laurel, Dog

1 Laurel, Sheep 17

4 Leather Wood

3 (Leucothoe) -

35 Locust, Rose _-_____-_ 1

9 Loosestrife

4 Maple _._._._._._._ 1

9 Meadow Sweet

33 Mistletoe _-__-____-_ 10

36 Moonseed _.

7 Moonseed

2 Mock Orange _._______-_ 22

25 Mountain Tea

37 Mulberry, Bermuda _._._. 9

9 Muscadine _.________- 32

9 Myrtle, Sand

10 Myrtle, Wax

3 New Jersey Tea _._____ 24

38 Nine Bark 23

11 Oak _._._._._._._. 1

11 Oil Nut _... 16

28 Old Man's Beard

25 Palmetto, Dwarf _-______ 4

16 Papaw _._._._. 15

Fever Bush

$\begin{array}{llll}\text { Fish Wood } \ldots \ldots \ldots \ldots \ldots & 22 & \text { Pepper Bush } \ldots \ldots & 17\end{array}$

Flowering Moss

28 Pepper, Mountain 
Pepper, Sweet

Poison Oak

Poison Vine

(Polygonella)

Pond Bush

Prickly Ash

Privet

Queen of the Meadow

Raspberry

Rattan

Red Haws

Red Root

Reed

Rhododendron

Rock Rose

Rose

Rose Locust

(Sageretia)

Sarsaparilla

Sarsaparilla, Big

Scuppernong

Sheep Berry

Spanish Bayonet

Sparkleberry

Spice Bush

Stagger Bush

(Stillingia)

Strawberry Bush

(Stuartia)

(Styrax)
20. Sumach

15 Supple Jack

36 Sweet Brier

29 Sweet Fern

13 Sweet Leaf

1323 Sweet Shrub

13 Syringa

23 Tangle Legs

10 Thorn Tree

35 Toothache Tree

5 Trailing Arbutus

24. Trefoil, Shrubby

28 Trumpet Flower

18 Virginia Creeper

28 Virgin's Bower

11 Wax Work

1 Wayfarer's Tree

35 Wicky i

34 Wild Appslice

37 Wild Ginger

32 Willow, Gray

12 Willow, Bush

15 Willow, Silky-leaved

Winterberry

Wintergreen

13 Wistaria

17 Witch Hazel

22 Woodbine

22 Yellow Root

23 Yellow Wood

22 Yopon 


\section{A TABULAR \\ VIEW OF THE SPECIES \\ ARRANGED ACCORDING TO THE CHARACTER OF THEIR FRUIT.}

FLEShy Fruit-

\section{S H R U B S}

Stone Fruit:

Plums, Fringe Tree, Oil Nut.

Large Fleshy:

Papaws, Spanish Bayonet, Bear Grass, Roses.

Red:

Red Haws, Barberry, Bermuda Mulberry, Huckleberry, Creeping Huckleberry, Bearberry, Cranberry, Elder, Coral Berry, Chokeberry, Yopon, Dahoon Holly, Sumach, Poison Oak, Flowering Raspberry, Mountain Tea, Spice - Bush, Pond Bush, Leather Wood, (Ilex)*.

BERRIES-

Black or Blue:

Black Haws, Gallberries, Dogwood's, Privet, Carolina Buckthorn, Prickly Ash, Elder, Dwarf Palmetto, Gooseberries, Currants, Huckleberries, Sparkleberry, Blackberries, Dewberry, Raspberry.

Whitish:

Mistletoe, Deerberry, Dogwoods.

DRY FRUIT-

Nuts:

Hazel, Buckeye.

Nutlets:

Witch Hazel, Button Bush, Dwarf Alder, Wax Myrtle, Sweet Fern.

Tassels and Cones:

Willows, Alder, Arbor Vitae.

Bladdery:

Bladder Nut, Sweet Shrub.

Flat and Winged:

Maples, Hop Tree.

Naked Seed:

Marsh Elder, Groundsel.

Grass-like:

Reed or Cane. 


\section{DRY CAPSUles-}

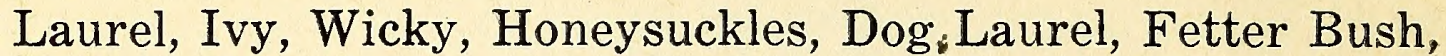
Pepper Bush, Stagger Bush (Andromeda), (Cassandra), (Leucothoe), Sweet Pepper Bush, (Itea), Sand Myrtle, He Huckleberry, False Heath, Syringa, Hydrangea, Hardhack, Queen of the Meadow, Bush Honeysuckle, Strawberry Bush, Burning Bush, Trailing Arbutus, (Hudsonia), Swamp Loosestrife, Toothache Tree, Indigo Bush, Mock Orange, (Stuartia), (Stillingia), (Darbya), (Buckleya), Red Root, Yellow Root, Rock Rose (Ascyrum), Flowering Moss.

*N.B.-Plants without a popular name are enclosed in parentheses and will be found also in the Index.

BERRIES-

\section{VINES}

Reddish:

Grapes, Woodbine, Bamboo, Poison Vine, (Cocculus).

Blackish:

Grapes, China Root, Bamboo, Sarsaparilla, Virginia Creeper, Rattan, Moonseed, (Sageretia), (Berchemia).

PoDs-

Trumpet Flower, Cross Vine, Jessamine, Virgin's Bower, (Forsteronia).

CAPSUles-

Bittersweet, Wild Ginger, (Decumaria).

NAKED AND Feathered SEEDS-

Virgin's Bower, (Atragene). 


\section{THE SHRUBS OF NORTH CAROLINA}

CHINQUAPIN OAK. (Quercus prinoides, Willd.) - Sometimes called Dwarf Chestnut Oak. Its foliage is somewhat like that of the Rock Chestnut Oak, and also has some likeness to that of the Chinquapin, which gives it its common name. It is a mere shrub, 2 to 4 feet high, of no value, and is here mentioned only to give a complete view of the genus. It is found very sparingly in the Lower District, but is not uncommon upon poor soils in the upper parts of the State.

BEAR OAK. (Q. ilicifolia, Wang.) - A. shrub, ordinarily about 3 to 5 feet high, extending from New York southward through the mountains of Virginia (where it is common) and North Carolina (very rare), to Georgia. The leaves are 2 to 3 inches long, cut about half way to the middle nerve into two divisions on each side, and with a white down on the underside. Worthless in itself, but a good indicator of barren soil.

Chinquapin. (Castanea pumila, Michx.)-This extends from the Delaware throughout the South. In this State it is known from the seaboard to Cherokee, and in great varieties of soil. It is usually a shrub from 6 to 12 feet high, but in cool fertile situations it is sometimes 30 or 40 , and 12 or 18 inches in diameter. The wood is finer grained than the Chestnut and equally durable; but the stock is too small for extensive use.

There is a distinct variety of this (var: nana) in our poor forests with slender shoots and extensive runners, bearing fruit at the height of a foot.

Rose LocUst. (Robinia hispida, Linn.) -A well-known ornamental shrub of our gardens, (sometimes known by the singular misnomer of Rose of Sharon, ) with large, deep rose-colored blossoms, bristly branches, flower-stems, and pods. It is indigenous to the rocky summits of mountains and hills in the Upper and Middle Districts; and a dwarf variety, in the Pine barrens of the Lower.

Mountain MaPle. (Acer spicatum, Lam.) - This has nearly the same range in the country with the Striped Maple. In this State it is found only in the Mountains, and is also a shrub 6 to 10 feet high. From its insignificance it does not seem to have attracted sufficient attention to acquire a popular name; but is known farther north by the above, and also as Low Maple. Europeans, who have paid far more attention than ourselves to the uses and capacities of our forest productions, have ascertained that this and the Striped Maple acquire double their natural size 
when engrafted on other species of Maple." Its leaves and fruit have the common characters of a Maple, the latter being rather small.

DAHOON HoLlY. (Ilex Dahoon, Walt.) - A shrub or small tree from 6 to 25 feet high, growing on the borders of the Pinebarren ponds and swamps of our Low Country, from Virginia to Florida. The leaves are 1 to 2 inches long, 1/4 to $1 / 2$ inch wide, entire, or with a few sharp teeth near the upper end, evergreen. The berries are red, as in the Holly and Yopon, and the plant is well worthy of cultivation.

YopoN. (I. Cassine, Linn.)-An elegant shrub, 10 to 15 feet high, but sometimes rising into a small tree of 20 to 25 feet. Its native place is near salt water, and it is found from Virginia southward, but never far in the interior. Its dark evergreen leaves and bright red berries make it very ornamental in yards and shrubberies. The leaves are small, $1 / 2$ to 1 inch long, very smooth, and evenly scalloped on the edges with small rounded teeth. In some sections of the Lower District, especially in the region of the Dismal Swamp, these are annually dried and used for tea, which is, however, oppressively sudorific,- - at least to one not accustomed to it. The Mate, or Paraguay Tea, of South America, is of the same genus as this, (the I. Paraguayensis,) but a very different species. Our Yopon is the article from which the famous Black Drink of the Southern Indians was made. "At a certain time of the year they come down in droves from a distance of some hundred miles to the coast for the leaves of this tree. They make a fire on the ground, and putting a great kettle of water on it, they throw in a large quantity of these leaves, and setting themselves around the fire, from a bowl that holds about a pint they begin drinking large draughts, which in a short time occasions thém to vomit freely and easily. Thus they continue drinking and vomiting for the space of two or three days, until they have sufficiently cleansed themselves; and then every one taking a bundle of the tree, they all retire to their habitations."

(I. decidua, Walt.) - This and the next three have deciduous leaves, and have not been honored in this State, as far as I know, with popular names. This is common along shaded ravines and branches throughout the Middle District, and is from 6 to 15 feet high. The leaves are 1 to 2 inches long, with rounded teeth on the edges, narrow and tapering down in to a short stem, somewhat hairy on the veins of the underside, otherwise smooth. Berries red, in clusters, each containing 4 to 6 bony seeds, that are ribbed on the back.

(I. ambigua, Chapm.) - A shrub or small tree confined to our mountain region in this State, though found elsewhere to the 
North and South, and from 8 to 20 feet high. The leaves are 3 to 5 and sometimes 6 inches long, about half as broad, with fine sharp teeth on the edges, smooth on both sides, and tapering at the upper end. The berries are red, not in clusters, and with seeds as in I. decidua.

(I. verticillata, Gray.) - This occurs in all the Districts, and in various soils, 2 to 10 feet high, and has clusters of bright scarlet berries which hang on through the Winter. In some States it is called Winterberry. The leaves are about 2 inches long, of varying width, but generally broader toward the upper end, coarsely toothed, paler and somewhat downy on the underside. The seeds are smooth and even. A decoction of the bark is a popular application to old sores.

GALLBERRY. (I. glabra, Gray.) - This and the next species are evergreen shrubs, indiscriminately called by the above name, sometimes Galls, more rarely Inkberries, names apparently derived from their black bitter berries. This is from 3 to 5 feet high, very common in the Branch swamps of the Lower District, and giving its name of Galls or Gallbays to the low places chiefly occupied by it. The leaves are very smooth and green, sparingly toothed, 1 to $1 \frac{1}{2}$ inch long, and about half that width.

TAlL Gallberry. (I. coriacea, Chapm.)-This grows in similar situations with the preceding, having the same habit and appearance, but full twice as large, the leaves also much larger, and either entire or with scattered sharp teeth.

SwAMP DoGwood. (Cornus sericea, Linn.) - This and the remaining species of the genus are only shrubs, but are placed here for the purpose of having all the species of a genus together, as $I$ have done in other genera. With the exception of the last species, they all have their leaves opposite, as in the Dogwood. This is the only one of them which has received notice enough in this State, so far as I have discovered, to get a name. It is found in low woods in the Middle and Upper Districts, has purplish branches, is from 6 to 10 feet high, and having rather broad, pointed leaves, which are smooth above and with a silky down beneath. The flowers are white, in flat-topped clusters, succeeded by pale-blue berries.

(C. stricta, Linn.) - This is 6 to 15 feet high, with brownish or reddish branches, found only in the wet lands of the Lower District. The leaves are about 3 inches long and 1 inch wide, tapering to a point at the upper end, the edges slightly uneven, smooth on both sides, paler and with prominent veins on the underside. The flowers and pale-blue berries are much as in C. sericea. 
(C. paniculata, L'Her.) - A branching shrub, 4 to 8 feet high, with gray branches, found in this State only in our mountain counties. The leaves are only 2 to 3 inches long, with a tapering point, smooth, whitish on the underside. The white flowers are in longer and looser clusters than in the two preceding, and the berries white.

(C. alternifolia, L'Her.) - I have met with this only on the higher mountains. It is the only one of this genus of Cornelsthis being the common name of the shrubby Dogwoods-which has the leaves alternating on the branches, instead of being opposite to each other in pairs. It is 10 to 15 and 20 feet high, the branches also alternate, greenish, streaked with white. The leaves are about 3 inches long, hoary and slightly hairy beneath, and pointed at the end. The flowers are whitish, in a loose flat topped cluster; the berries dark blue or bluish black.

Dwarf PalmetTo. (Sabal Adansonii, Guerns.) - This is but 3 or 4 feet high, never forming a trunk, and found only in the Lower District. The leaves are employed in the manufacture of palm-leaf hats.

YELLOW Wood. (Symplocos tinctoria, L'Her.)-Also called Sweet Leaf and High Bush Laurel. It does not extend much, if any, north of James River. In this State it occurs from the coast to the mountains, but is most multiplied in the Lower District. In poor soils it is only a shrub 2 to 6 feet high; but in those which are fertile, as on the borders of swamps, it becomes a small tree, 20 to 25 feet high and 6 to 8 inches in diameter. If the trunk be wounded in Spring, it exudes a milky, offensive juice. The leaves, which are 3 to 5 inches long, are sweet to the taste but rather dry, and greedily eaten by cattle and deer in Winter. They afford, by decoction, a beautiful yellow color, which is fixed by a little alum, wherewith cotton, woolen and silk, are dyed. It is not much used, however. The fruit is a small one-seeded berry. The wood is soft and valueless.

CHOKe BerRy. (Pyrus arbutifolia, Linn.)-A mere shrub 2 to 3 feet high, introduced here only to complete an account of the genus. The fruit is berrylike, as in the Mountain Ash, but has the same structure as an apple, with seeds of the same appearance and taste. It grows in small clusters, and is rather dry and astringent. We have two varieties of this:-one, with a red or purple fruit, found on the borders of branches and bays in the Middle and Lower Districts;-the other, in the mountains, and having a purplish-black fruit.

Gray WILlow. (Salix tristis, Ait.) -A shrub 1 to 2 feet high, very much branched, of a dull gray aspect on account of the young branches and leaves being covered with an ash-colored 
down or wool. The leaves are from 1 to $11 / 2$ inch long with a hardly perceptible stem, narrow, sharp at each end, but tapering from the base towards the upper end, and with the veins prominent on the underside. I have met with this insignificant plant only in the mountain counties.

Bush Willow. (S. humilis, Marsh.) -Larger than the preceding, 2 to 4 feet high, but of similar general aspect, the leaves two or three times longer and broader, and found both in the Middle and Upper Districts, rarely in the Lower. During Summer the branches of this and Gray Willow have cone-like excrescences on their ends.

Silky-Leaved Willow. (S. sericea, Marsh.) -This is 3 to 6 feet high, with leaves 2 to 3 inches long, borne on conspicuous stems, pale, and with silky hairs on the underside.

RED HAWS.-Thorny shrubs, sometimes tree-shaped, with white flowers, mostly in flat topped clusters, and colored (generally red) fruit containing 1 to 5 bony seeds.

1. Scarlet Haw. (Cratægus coccinea, Linn.)-Grows in the Middle and Upper Districts, 6 to 12 feet high, with stout thorns 1 and 2 inches long. The leaves are smooth and thin, about 2 inches long and broad, cut into several small segments on each side. The fruit is bright red, $1 / 2$ inch or more long, and eatable.

2. WAshington Thorn. (C. cordata, Ait.) - I have seen this only in the Middle District. It is a very beautiful shrub when in blossom, as may be seen on the Cape Fear near Averasboro in May. It is from 10 to 20 feet high, the thorns about 2 inches long, and rather slender. The leaves are 2 to 3 inches long, cut into 3 divisions somewhat like those of the Red Maple. The fruit is bright crimson, about $1 / 4$ inch long.

3. Parsley-Leaved HaW. (C. apiifolia, Michx.) - This, so closely resembling the Hawthorn of England, is found in the Lower and Middle Districts. The leaves are about 1 inch long, and much cut up into small divisions, from which this handsome shrub or small tree derives its name, and by which it is easily distinguished from all the other species. The fruit is red and about $1 / 4$ inch long.

4. Cockspur Thorn. (C. Crus-galli, Linn.)-The most abundant of our Thorns or Haws, and found in all the Districts. It is 10 to 20 feet high and armed with sharp thorns 2 inches or more long. The leaves are about 2 inches long, rather thick and stiff, shining green above, somewhat tapering from the upper part downward, and toothed above the middle. The fruit is red, about $1 / 3$ inch long. This is our best species for hedging. But it 
should be remembered that none answers well if left at random to an upward growth, and is not well laid and so regularly trimmed or cut in as to take a lateral growth and to branch freely near the ground.

5. BLACK THORN. (C. tomentosa, Linn.) - A shrub or small tree in the Middle and Upper Districts, with large clusters of flowers, which are $3 / 4$ inch or more broad, and a round or pearshaped, edible fruit, which is orange-red and about $3 / 4$ inch long. The leaves are 3 to 5 inches long, of an oval or oblong form, finely toothed and sometimes cut at the summit, somewhat hairy on the underside, and more or less furrowed along the veins above.

There is a form of this (var: punctata, Gray) very common on the tops of our mountains, with the leaves smaller, more narrowed towards the base, and the furrows on the upper surface deeper, and the veins more prominent beneath. The fruit is round, yellowish or dull red, sprinkled with whitish dots.

6. NARrow-Leaved Thorn. (C. spathulata, Michx.) -Not uncommon in the Lower and Middle Districts, 10 to 15 feet high, with quite small flowers and fruit, but rather ornamental. The leaves are smooth and shining, $1 / 2$ to $11 / 2$ inch long, $1 / 4$ to $1 / 2$ inch wide, toothed at the upper end and tapering from near the top down to the stem. The fruit is red and in numerous clusters.

7. Sum Mer Haw. (C. flava, Ait.) - A small tree 15 to 20 feet high, in sandy woods, with fruit $1 / 2$ to $2 / 3$ inch thick, pear-shaped, and greenish-yellow. The leaves are 2 to 3 inches long, wedgeshaped, the lower part tapering into a short stem with small dark glands on the edges. The flowers but from 2 to 5 in a cluster.

8. Hairy Thorn. (C. glandulosa, Michx.) - A small tree with coarse bark and spreading branches, and the leaves, branchlets and flower stems covered with soft hairs, especially when young. The leaves are about 1 inch long, rather thickish, wedge-shaped, the edges generally dotted with dark glands. The fruit is small, round, and red. The flowers are 3 to 6 in a cluster.

9. DWARF THORN. (C. parvifolia, Ait.) - A small shrub 2 to 5 feet high, very common in sandy woods throughout the Lower and Middle Districts, and with a whitish down on most of its parts. The leaves are $1 / 2$ to $11 / 2$ inch long, broad, wedge-shaped, toothed, with hardly any stem. Flowers solitary, or 2 or 3 together. Fruit round or pear-shaped, greenish-yellow, rather large and dry.

BARBERry. (Berberis Canadensis, Pursh.)-Found in Lincoln, thence westward, especially in Buncombe, Haywood and Macon Counties. It is not known to exist north of Virginia, and is the only native Barberry in the United States. The European species 
(B. vulgaris) is thoroughly naturalized in New England. Ours is a pretty shrub, 2 to 4 feet high and somewhat prickly. The fruit is an oblong, red and acid berry, which makes an agreeable conserve, and a cooling drink in fevers. The leaves are also slightly acid. It is probable that this, like the European species, which it closely resembles, would furnish a yellow color by boiling the roots in lye; and that the inner bark of the stems would dye linen of a fine yellow with the assistance of alum.

GOOSEBERRIES AND CURRANTS.-These belong to one genus, but are distinguished-the former, by the small sharp thorns at the base of the leaves, sometimes the fruit being prickly, and generally (always in the North Carolina species) by the flower stems having from 1 to 3 flowers; the latter, by the absence of thorns, smaller fruit (never prickly), and the flowers numerous in long clusters. They are found only in the mountains.

1. Prickly Gooseberry. (Ribes Cynosbati, Linn.)-Distinguished from the others by its prickly fruit, which is brownish when ripe, and eatable.

2. SMоOTH GooseberRy. (R. rotundifolium, Michx.)-This is 3 to 4 feet high, the leaves 1 to 2 inches broad, about half the size of the preceding, the fruit small, purple when ripe, and of fine flavor.

3. Slender Gooseberry. (R. gracile, Michx.) - Very similar to No. 2, but every way more slender and delicate, and quite rare.

4. Fetid CURRant. (R. prostratum, L'Her.)-Occurring chiefly upon rocks on our highest mountains and generally spreading on the ground. The berry is covered with bristles and is not pleasant flavored. The whole plant exhales a disagreeable musky odor, which will readily distinguish it.

5. Bristly Currant. (R. resinosum, Pursh.) - This was discovered in our mountains by Fraser. I have not myself met with it. It is covered in every part, not excepting the fruit, with resinous glandular hairs, by which it may be recognized.

HUCKLEBERRIES.-The fruit so called in this State is comprised in two genera; the first (Gaylussacia) including those which have a black or blackish berry, and leaves generally covered with small glandular dots; the second (Vaccinium) including those with a blue, red or greenish berry. The blue ones are known in some States as Blueberries or Bilberries. The red are Cranberries. The greenish one is in this State called Gooseberry and Deerberry.

1. Blue Huckleberry. (Gaylussacia frondosa, Torr. and Gr.) - Common in the Lower and Middle Districts on the borders 
of low grounds, 2 to 3 feet high, with pale, somewhat wrinkled leaves, which are whitish underneath, and 1 to 3 inches long. The berries are dark blue, large and sweet, perhaps the finest flavored we have, ripening in June.

2. Dwarf Huckleberry. (G. dumosa, Torr. and Gr.) - A low species about a foot high, with creeping roots, very common in dry woods of the Lower and Middle Districts. It is somewhat hairy and glandular, the leaves broad, wedge-shaped, green on both sides, and the fruit smooth, black and insipid. A larger form of this (var: hirtella) has the berries also hairy.

3. Black Huckleberry. (G. resinosa, T. and Gr.)-Belongs to the Middle and Upper Districts, 2 to 3 feet high and much branched. The leaves are 2 to 3 inches long, and thickly sprinkled with resinous atoms. The berries are black, shining and very pleasant. There is a white variety of this, found in the mountains by Mr. Buckley.

4. Bear Huckleberry: Bearberry. (G. ursina, Gray.)Found in the sides of the mountains south of the French Broad River, 2 to 3 feet high, and resembling No. 3. But in the latter the flowers are cylindrical; in the Bearberry cup-shaped. The berry is purplish or dark red, insipid and dry, ripening in July and August.

1. SWAMp HuckleberRY. (Vaccinium corymbosum, Linn).Abundant in swampy grounds of the Lower and Middle Districts, and probably extending into the Upper. It is from 5 to 10 feet high, with very variable leaves, but generally thin, pale and smooth. The berries are large, deep blue, subacid and pleasant, ripening in May and June.

There is a variety of this (var: atrococcum, Gray), having a similar range and locality and size, but much less common, with thicker leaves, which are white-downy underneath, and with berries dark blue. Dr. Hunter finds this variety with a white berry in Lincoln and Burke Counties.

2. Pale DWarf Blueberry. (V. Constablæi, Gray.) - About 1 foot high, abundant on the bald summit of Roan Mountain (where it was first discriminated by Prof. Gray,) and not unlikely on others. It is of a pale whitish aspect, with leaves 1 to 2 inches long, and blue sweet berries.

3. (V. tenellum, Ait.)-Common on the borders of small swamps in the Lower District and extending somewhat into the Middle; about 2 feet high, with green, angled branches. The leaves are $1 / 2$ to 1 inch long, narrow, wedge-shaped, slightly toothed at the top, and of a bright green. Berries black, small, of little worth. 
4. Bristly HuckleberRY. (V. hirsutum, Buckley.)-Discovered in the Cherokee Mountains by Mr. Buckley, and easily recognized by its bristly branches, leaves, flowers and fruit.

5. DeErberry. Gooseberry. (V. stamineum, Linn.)-Very common all over the State in dry woods, 1 to 4 feet high, and very pretty when in blossom. The berries are greenish-white, sour and astringent, larger than any other of our Huckleberries.

6. (V. erythrocarpon, Michx.) - A shrub 2 to 4 feet high, found upon Grandfather, Flat Top and Roan Mountains. The leaves are rather hairy and with small teeth on the edges. The flowers have long divisions that are rolled backwards precisely like those of the Cranberry. The fruit is small, reddish or purplish, and insipid, somewhat like that of the Bearberry.

7. SPARKLEberRy. (V. arboreum, Michx.) - Found from the coast to Cherokee, 8 to 20 feet high, the leaves smooth, rather stiff and shining. They are evergreen, at least in the Lower District. The fruit is black and small, dry, granular and slightly astringent, but of pleasant flavor, ripening in October. When in blossom it is quite a showy shrub. The bark of the root is very astringent, and is used in chronic dysentery.

8. CREeping HUCKLEBerRy. (V. crassifolium, Andr.)-A small species with stems ( 1 to 2 feet long) creeping close upon the earth in wet savannas of the Lower District. The leaves are small, $1 / 4$ to $1 / 2$ inch long, evergreen, thick and shining. The fruit is red, becoming black, tasteless.

9. CRANBerRy. (V. macrocarpon, Ait.) -A small trailing plant with pale evergreen leaves, common in the mountain swamps of Ashe and Yancey, and also in Pasquotank, Hyde and other counties in the north-eastern part of the State. The fine acid fruit of this plant is well known and universally esteemed.

CORAL BERRY. (Symphoricarpus vulgaris, Michx.) - A small shrub, 2 to 3 feet high, frequent in arid gravelly soils, especially by road sides, throughout the Middle District. The leaves are rather stiff, about 1 inch long, downy beneath. The flowers are of no beauty, but the compact clusters of dark red berries in the fork of nearly all the leaves, and which hang on through the Winter, have made it an object of attention among gardeners and florists. This is sometimes so much of a nuisance on plantations, on account of its creeping tangled roots, as to have gained the uncouth name of Devil's shoe-strings.

Bermuda OR FRench MulberRy. (Callicarpa Americana, Linn.) - Quite common in light soils and dry, open woods of the Lower District, especially along fence-rows and the borders of settlements. It is 3 to 6 feet high, with coarse, rough, grayish 
unsightly leaves, which are 4 to 5 inches long and round-toothed on the edges. But in Winter the numerous clusters of lightpurplish berries which encircle the summit of the branches at regular intervals for 12 or 18 inches, give it a very striking and pleasing appearance. These berries are juicy, slightly aromatic and sweetish, and are sometimes eaten, but are probably not very wholesome.

Mistletoe. (Phoradendron flavescens, Nutt.) -Well known throughout the State, and needing no description. With us it seems to prefer the Oaks and Locust, but at the North and West, Elms and Hickories. Deer are very fond of this plant. This is a different plant from the European Mistletoe, the aureus ramus of Virgil.

1. High Blackberry. (Rubus villosus, Ait.)-This is our common Blackberry of the swamps and fallow lands, 4 to 10 feet high, and the leaves slightly hairy or smooth, and green on both sides. It is found throughout the State. The root of this is slightly astringent, and is a popular remedy for diarrhœa.

2. Low Blackberry, (R. cuneifolius, Pursh.)-Common in old fields and by road sides in the Lower and Middle Districts, 2 to 4 feet high, the leaves white and downy beneath. Smaller in all parts than No. 1, the berries generally sweeter.

3. DewberRy. (R. trivialis, Michx.) - Generally well known under this name, but most abundant in the Middle District. This is a trailing species with smooth green leaves, growing mostly in dry soils, and with larger, sweeter fruit than the preceding.

4. SWAMP BlaCKBERRY. (R. hispidus, Linn.) -A prostrate species like the preceding, found in the mountain swamps, but every way more delicate, with thinner leaves, and with weak prickles that hardly deserve the name. Fruit black, small and sour.

5. BlACK OR PURPle RASPBERRY. (R. occidentalis, Linn.) Grows on the borders of woods and in thickets through the Middle District. The fruit is very pleasant but rather dry, and much inferior to the cultivated species.

6. Flowering RASPBERRY. (R. odoratus, Linn.) - Found only in the mountains along rivulets and in cool, shaded ravines. This is without prickles, but is covered with clammy hairs, is 4 to 5 feet high, and has leaves 6 to 7 inches long, divided into about 5 short segments. The flowers are quite ornamental, about 2 inches broad and looking like a small single Rose. The fruit is broad, red and dry, but pleasant flavored. 
1. Swamp Rose. (Rosa Carolina, Linn.) - This is from 3 to 6 feet high, is generally confined to low damp grounds, and has stout, hooked prickles.

2. WILD OR DWARF Rose. (R. lucida, Ehrh.) - Generally prefers dry soils, and is found in all the Districts. It is about half the size of No. 1, has the leaves shining on the upper side, and has straight prickles, which will distinguish it from the preceding.

3. SWEET BRIER. (R. rubiginosa, Linn.)-Extensively naturalized along roads and about settlements, especially in the Middle District, and easily recognized by the pleasant fragrance derived from the rusty colored glands on the underside of the leaves. This is sometimes known as the Eglantine.

4. Cherokee Rose. (R. lævigata, Michx.I) - Cultivated in the Lower and Middle Districts, often trained over fences, and, if well managed, serves well for hedging. It is remarkable for its smooth, dark, evergreen leaves and white single flowers. It is singular that the native region of this Rose is unknown.

1. Elder. (Sambucus Canadensis, Linn.)-There is no portion of the State, except the higher parts of the Mountains, where this shrub is not found. Its leaves are smooth and its berries dark purple. The inner bark is of popular use in ointments for sores. An infusion of the leaves is sometimes used for expelling insects from vines, \&c. An infusion of the dried flowers is a domestic remedy for colds. The ripe berries afford a delicate test for detecting acids and alkalies.

2. RED-BerRied Elder. (S. pubens, Michx.)-Grows only on the higher Mountains above the range of the preceding, from which it is at once distinguished by its red berries and the downy underside of its leaves. It belongs chiefly to a high latitude.

1. BLACK HAW. (Viburnum prunifolium, Linn.)-Common in rather dry rich soils from the coast to the lower part of the Upper District, 8 to 15 feet high, handsome when in flower. The blossoms are small, white, in flat clusters, which are two or three inches broad, and destitute of a common stem. The leaves, 1 or 2 inches long, are smooth and shining above. The fruit is about half an inch long, bluish-black, sweetish and eatable.

2. Possum Haw. (V. nudum, Linn.) - Has a similar range with No. 1, and grows in cold swampy grounds, 6 to 12 feet high. The flower-clusters in this are supported on a short commonstem. The leaves are larger and of thicker texture than in the former, dull green above, and covered with rusty scales beneath. The fruit is a deep blue. In the Mountains I have heard this called Shawnee Haw. 
There is a form of this (var: angustifolium), with smaller, narrower, and brighter leaves, which I have met with in Henderson County.

3. (V. obovatum, Walt.) - A shrub or small tree, growing on the banks of streams, but not common in this State. The leaves are $1 / 2$ to 1 inch long, rather thick, smooth, broader at the upper end, and faintly toothed. The flower-clusters are without a general stem. The fruit is black.

4. Sheep Berry. (V. Lentago, Linn.) - Found only in the Mountains, 10 or 15 feet high. The leaves are rather thin, 3 to 4 inches long, smooth, with a tapering point, sharply toothed, their stem and middle nerve beneath, together with the flower branches, sprinkled with rusty atoms. The fruit is first red, then bluish-black, and is eatable when fully ripe.

5. Arrow-Wood. (V. dentatum, Linn.)-Grows in low grounds of the Lower and Middle Districts, but is not very common. It is 8 to 12 feet high, with ash-colored bark, and by the flowers and fruit would be at once recognized as belonging to the same genus as Nos. 1 and 2. The leaves are roundish, 2 or 3 inches long, coarsely and sharply toothed, thin and smooth, the lateral veins quite straight, and deeply impressed above. The fruit is roundish and deep blue, and slightly rough. The young straight branches of this were used by the Indians for making arrows.

6. Downy ARRow-WOod. (V. pubescens, Pursh.)-Very similar to No. 5, but smaller, 3 or 4 feet high, the underside of the leaves downy, and growing only in the rocky soil of the Mountains.

7. MAPle-LeAved ARrow-Wood. (V. acerifolium, Linn.) -A shrub 2 to 5 feet high, found in the Mountains and on rocky hills of the Middle District, as low down as Orange, with leaves 3 or 4 inches long, shaped like those of a Maple. The berries are whitish, becoming purplish-black. The slender stems, by removing the pith, make good fuse-sticks for blasting, and will serve equally well for blasts of tobacco-smoke.

8. Hobble-Bush. Tangle-Legs. (V. lantanoides, Michx.) A small straggling shrub found in cold, damp places in the Mountains. The branches spread upon the ground, and, taking root at their ends, form well secured loops for tripping the feet of inexperienced wayfarers; a habit which has been revenged upon by the unlucky, in the names imposed upon it of American Wayfarer's Tree and the Devil's Shoe-strings. The leaves are 3 to 6 inches broad, heart-shaped, very veiny, the underside having a rusty down. The berries are first crimson, then black. The 
flowers on the margin of the broad clusters of this species are very large (by abortion), like those of the well-known Snow-ball of our Gardens, which is a species (V. Opulus) of this genus.

PRICKLy Ash. (Aralia spinosa, Linn.) - Found in tolerably rich soil from the coast to Cherokee, but not very abundant in any locality. It is seldom 20 feet high with us, and is remarkable for its straight, club-shaped, prickly stem or trunk, with the compound leaves spreading like those of a Palm trom its summit. An infusion of the fresh bark of the root is emetic and cathartic, and is employed, as are also the berries, in spiritous infusion, in rheumatic affections. These are thought by some to be also a valuable remedy for the bite of a rattlesnake.

PRIVET. (Ligustrum vulgare, Linn.)-Occasionally naturalized about settlements. Berries black. This is suited for low hedges.

1. SPICE Bush. (Benzoin odoriferum, Nees.) -Known also as Spice Wood, Wild Allspice, and F'ever Bush. Grows in damp woods throughout the State, and, wherever found, known under one or other of these names. It is a strongly scented shrub, smooth, 3 to 6 feet high, with dark red berries, and leaves 3 or 4 inches long. An infusion of the twigs is sometimes used in country fevers, and for sickly cattle in the Spring.

2. (B. melissæfolium, Nees.) - Belongs to the Lower and Middle Districts in low grounds and on the borders of shallow ponds, 2 or 3 feet high, leaves silky on both sides, 1 or 2 inches long, slightly heart-shaped; berries red. I am indebted to Dr. McRee and Prof. Mitchell for my knowledge of this species.

Pond Bush. (Tetranthera geniculata, Nees.) - Occupies small ponds in the Lower District, giving a gray smoky aspect to these localities. It is rarely met with in the lower part of the Middle District. It is 10 or 15 feet high, with smooth, zigzag branches, and small oval leaves, $1 / 2$ to 1 inch long, and red berries.

This and the genus next preceding are closely related to the Sassafras, and, like it, have small yellowish flowers which appear before the leaves.

LEATHER-WOOD. (Dirca palustris, Linn.) - Widely diffused over the country, but in this State occurring sparingly upon shaded rivulets in the Middle and Upper Districts. It is 3 to 5 feet high, and the branches have such a tough and pliable bark that they make excellent ligatures, for which they were used by the Indians, and from which the shrub derives its name. The fruit is a small reddish berry. 
Carolina Buckthorn. (Frangula Caroliniana, Gray.)-A thornless shrub, 4 to 6 feet high, belonging to moderately fertile soils in the Middle and Lower Districts, but rare in the latter. The leaves are 3 or 4 inches long, 1 or 2 wide, dark green, smooth and shining, and ribbed with very straight parallel veins. The berry is blackish, of the size of a small pea.

1. SumACH. (Rhus copallina, Linn.) - Very common throughout the State, usually 6 to 10 feet high, sometimes a small tree 15 feet high, readily distinguished by its common leaf-stem being margined or winged between the leaflets. The crimson hairs on the berries possess a strong acid, (said to be Malic,) an infusion of which, with sugar, makes an agreeable cooling beverage, and, without sugar, is a very useful gargle for weak or sore throats.

2. Sмоотн Sumach. (R. glabra, Linn.)-This is 6 to 10 feet high, growing in the Middle and Upper Districts, and is remarkably smooth in all its parts. A milky juice issues from the wounded bark. The large clusters of red fruit are more compact than in No. 1, having an acid secretion as in that. The branches and leaves are astringent, and are used for tanning.

3. Staghorn Sumach. (R. typhina, Linn.)-Belongs to the Upper District, 10 to 20 feet high, the branches and flower stalks densely and rather softly hairy, somewhat like a Deer's horn "in the velvet." The leaflets are narrow and tapering. The bark issues a milky juice, and the berries are acid, as in No. 2. The wood is orange colored and aromatic. The bark and branches are used for tanning. The large clusters of purple fruit, and a fine foliage, render this species quite ornamental.

4. DWARF Sumach. (R. pumila, Michx.) - This has a general resemblance to No. 3, especially in the dense hairiness of the young branches, but the leaflets in this are much shorter, broader and more coarsely toothed, and the plant is only 1 to 3 feet high, mostly spreading over the ground. It is rather rare, but occurs in the Lower and Middle Districts, especially in Mecklenburg, where it was originally discovered by the elder Michaux: Pursh has represented it as being very poisonous, but it is perfectly harmless, as are all the preceding species.

5. Poison Sumach. (R. venenata, DC.) - Found in all the Districts in cool swampy situations, where it is somewhat conspicuous by its smooth green bark and pink-colored leaf-stems. To most persons it is exceedingly poisonous, some even being affected by proximity to it, especially while rain or dew is evaporating from it. Others, however, can handle it with safety. The juice of this is a good varnish, like that of the Japan Sumach ( $R$. vernicifera), which is a very similar and was once supposed to be the same species. 
6. PoIson OAK. (R. Toxicodendron, Linn.) - A small shrub, 1 to 2 feet high, well known by this name from the coast to the lower part of the Upper District. It is less poisonous than No. 5, but is too mischievous to be meddled with by persons who are sensitive to this class of poisons. The juice is an indelible ink upon linen.

It has been stated very positively in some quarters that the dreaded disease, known in our Mountains and at the West by the name of Milk Sickness, is caused by the cattle eating of this Poison Oak. But our Lower and Middle Districts abound in this plant, where this disease is not now heard of, while in those portions of the Mountains where cattle are affected with it, and which I have examined with special reference to ascertaining its origin, this plant is not found, nor any other poisonous plant which is not common elsewhere. Besides, it is well known that cattle do not take the disease if kept from those grounds till the dew has evaporated. Its cause is yet a mystery, but I am satisfied it is telluric.

The Mountain Tea or Wintergreen, (Gaultheria procumbens, Linn.) so well known in the Mountains, rarely in the other Districts, for its aromatic spicy leaves and berries, is an evergreen shrub, but so small that it would not generally be considered such.

The next two genera have a fleshy fruit, but too large to come under the class of Berries. They are well known by their names.

1. PAPAW. (Asimina triloba, Dunal.) - Not uncommon in rich bottom lands of the Middle District, 10 to 15 feet high, but in the primitive soil of the Western States sometimes 30 feet. The flowers are dull dark-purple, over an inch wide. The fruit is about 3 inches long by $11 / 2$ thick, yellow, and filled with a soft sweet pulp which is edible, but does not seem to be agreeable to most persons. The bark of the trunk and root exhales a very heavy unpleasant odor. The wood is remarkably light and spongy.

2. DWARF PAPAW. (A. parviflora, Dunal.) - A small shrub similar to No. 1, but smaller every way, found in waste grounds in the Lower District, and in thin woods of the Middle and lower part of the Upper District. It is from 2 to 5 fet high, the leaves 4 to 6 inches long, (about half the size of the preceding,) the greenish-purple flowers $1 / 2$ inch long and of unpleasant odor. Fruit in clusters, about an inch long.

1. SPANish BAYonet. (Yucca aloifolia, Linn.) - A native of the coast from North Carolina southward, frequently cultivated in the Lower District, and very showy when capped by its large 
cluster of white bell-shaped flowers. It is 4 to 8 feet high, its stiff leaves (12 or 18 inches long) tipped with a very sharp thorny point, and their edges very rough.

2. (Y. gloriosa, Linn.) - Found also on the sandy coast, similar to the preceding, but smaller, and the leaves smooth on the edges.

3. BEAR Grass. (Y. filamentosa, Linn.)-Common in sandy fields nearly throughout the State, well known by the thread-like filaments on the edges of the leaves, and admired for the beauty of its flowers, borne in clusters upon a naked stem 4 to 6 feet high.

The two next genera would be most generally ranked among Stone-fruit, though the shell of the second is very thin, and covered by a very thin flesh.

FrINGE TREe. (Chionanthus Virginica, Linn.) - Sometimes called Old Man's Beard. We have no shrub of softer and more delicate beauty than this, when draped in its clusters of snowwhite, fringe-like flowers. It is found northward to southern Pennsylvania. In this State it grows in all the Districts, but most abundantly in the Middle. It is sometimes 15 to 20 feet high, but flowers at the height of 2 or 3 feet. Its fruit has the appearance and odor of a green plum, but I have never seen it produce fruit in the Lower District. An infusion of the roots is a favorite remedy in long standing intermittents and other chronic diseases.

Oil-nut. Buffalo Tree. (Pyrularia oleifera, Gray.)-A bush 3 to 6 feet high, abundant through our mountain range, and reaching north to the mountains of Pennsylvania. The leaves are 3 to 4 inches long, becoming smooth, rather acrid to the taste, and oily. The fruit is an inch or more long, pear-shaped or roundish, with a thin shell and large oily kernel. The root has. an unpleasant odor.

The remaining Shrubs, including those with Nuts, are Dryfruited and very various. The first Group will include such as have dry seed-covers, containing small seeds and opening by partitions. The first three genera have tubular small flowers like those of the Huckleberry and Sorrel Tree.

1. Fetter-Bush. (Andromeda nitida, Bartr.)-Found only in the Lower District in low Pine barrens. It is 2 to 5 feet high, with the branches three-angled, smooth throughout; the leaves evergreen and shining and rather thick, 1 to 2 inches long, not toothed; the flowers clustered in the forks of the leaves, white or reddish, with a sort of honey odor, opening in March and April. 
2. StAGger-Bush. (A. Mariana, Linn.)-Grows in the Lower and Middle Districts, on the margin of low grounds. It is 2 to 3 feet high and smooth. The leaves are 1 to 2 inches long, not toothed, dull green; the flowering branches generally destitute of leaves; the flowers in clusters along the branches, near $1 / 2$ inch long, white and showy, opening in April and May.

3. (A. speciosa, Michx.) -A very handsome shrub growing in low wet grounds of Pine barrens in the Lower District, 2 to 5 feet high and smooth. The leaves are 1 to $11 / 2$ inch long, toothed, dull green, sometimes covered on the underside with a very white bloom. The flowering branches are free from leaves, 6 to 12 inches long and very showy. The flowers are larger than in No. 2, more bell-shaped, opening in May.

4. Pepper-Bush. (A. ligustrina, Muhl.)-This occurs in all the Districts, but only in the lower part of the Upper. It is 3 to 4 feet high, somewhat hairy. The leaves are about 2 inches long, sharp pointed, finely toothed, paler underside. The flowers are small, almost globular, scurfy, in small clusters that are leafy.

5. (A. floribunda, Pursh.) - Rather rare, and belonging to the mountains, 4 to 8 feet high, the younger branches reddish and covered with scattered stiff hairs and glandular dots. The leaves are 1 to $11 \frac{2}{2}$ inch long, evergreen and rigid, rounded at base, sharp at top, minutely scalloped, the youngest with short hairs on the margin; flowers in crowded leafy clusters.

1. Dog Laurel. (Leucothœ Catesbæi, Gray.) - Found only in the mountains, where it is also called Hemlock, growing on the cool margins of streams. It is 2 to 4 feet high, the leaves evergreen, 3 to 5 inches long and 1 inch broad, with a long tapering point, prickly-toothed on the edges. Clusters of flowers in the forks of the leaves. A very pretty shrub.

2. (L. axillaris, Don.) - On the borders of streams and wet places in the Lower District, and very much like No. 1. But the leaves are less prickly-toothed, less tapering, 2 to 3 inches long, broader than in the preceding, the clusters of flowers longer, and the flowers longer.

3. (L. racemosa, Gray.) - Grows from the coast to the base of the mountains, 4 to 8 feet high, on the borders of wet places. The leaves are rather thin, acute, finely toothed, 1 to $11 \frac{1}{2}$ inch long. The flowers ( $1 / 2$ inch long) are on terminal straight branchlets, all hanging to one side, and looking like rows of teeth, the rows being 2 or 3 inches long.

4. (L. recurva, Gray.) - Discovered by Mr. Buckley in the mountains near Paint Rock. It is 3 to 4 feet high, the leaf and flower-branches recurved; the leaves broader and more hairy 
than in No. 3, rounded at base, finely toothed, scarcely tapering, 2 to 3 inches long, deciduous as in No. 3.

(Cassandra calyculata, Don.) - A small shrub, 2 to 3 feet high, growing in damp grounds of the Lower District, and not unlikely in the others. The evergreen leaves are about 1 inch long, $1 / 3$ inch wide, finely toothed, rather stiff, and covered, like the young branches, with small white scales. The flowers are on terminal branchlets, quite small, solitary in the forks of small leaves.

1. LAUREL. (Rhododendron maximum, Linn.)-This is rare north of Pennsylvania, but becomes abundant southward in the Alleghanies, and is common through their whole range in this State, where it often forms impenetrable thickets, many acres in extent. It also grows upon rocky hills in the Middle District as far east as Orange. Its usual height is 8 to 10 feet, but is sometimes as high as 20 feet. This is a production of great beauty and universally admired. The flowers, about an inch broad, grow in compact clusters on the ends of the branches, and are generally of a pale rose color, but sometimes whitish, dotted with green and yellow on the inside. These contrast pleasingly with the large thick evergreen leaves. The leaves and flowers are reputed poisonous. The wood is very hard and fine grained, but not equal to that of Ivy.

2. Oval-Leaved Laurel. (R. Catawbiense, Michx.)-This splendid Laurel is chiefly confined to the highest summits of our mountains, but is said to extend somewhat into Virginia. It is often confounded with the preceding, but besides its different locality, growing only on the tops of such mountains as the Roan in Yancey and Negro Mountain in Ashe, it blossoms earlier than the other, though at a higher elevation, has larger and more intensely colored flowers, and shorter and broader leaves. It is 5 to 8 feet high, and handsomer than No. 1. It stands cultivation pretty well in the Middle District.

3. DWARF LAURel. (R. punctatum, Andr.) - A rusty looking shrub, 1 to 2 feet high, chiefly confined to the mountains of North Carolina and Georgia. It has a strong family likeness to the other species, but is too inferior to them in every respect to attract or deserve much attention. I have met with it only on Table Rock, Jonas' Ridge and Whiteside Mountain.

1. Smooth HoneYsuckle. (Azalea arborescens, Pursh.)Found only along water courses in the lower part of the Upper District, and is 4 to 10 feet high. It is similar to the next, a common and well known species; but this has smooth branchlets, leaves of brighter green above, and long calyx appendages at the base of the flower. The flowers are white and roseate, and their 
odor may be perceived at a great distance; this being the most powerfully fragrant of our Honeysuckles. For cultivation this will rank next in beauty to the Yellow Honeysuckle.

2. Clammy Honeysuckle. (A. viscosa, Linn.)-Very common through the State, 2 to 6 or 8 feet high, the branchlets bristly, and the flowers covered with clammy hairs. The flowers are white or flesh-colored and very fragrant. In this and No. 1 the flowers appear after the leaves have expanded. In the next two species they appear before or with the leaves.

A variety of this (var: glauca) occurs with paler and rougher leaves, their underside covered with a white bloom.

3. Purple Honeysuckle. (A. nudiflora, Linn.) - Very common in great varieties of soil through the State, 2 to 6 feet high, but usually very small in poor dry soils. - The flowers vary from a flesh-color to pink or purple, and are sometimes quite white. They are destitute of fragrance.

4. Yellow Honeysuckle. (A. calendulacea, Michx.)-This is found only at a considerable elevation on our mountains, where it is abundant and well known by the name here given. It is commonly from 3 to 6 feet high, and varies very much in the color of its flowers, but most frequently they are some shade of yellow. Bartram, in his "Travels," calls this the Fiery Azalea, and says: "This epithet Fiery I annex to this most celebrated species of Azalea, as being expressive of the appearance of its flowers, which are in general of the color of the finest red lead, orange and bright gold, as well as yellow and cream color. These various splendid colors are not only in separate plants, but frequently all the varieties and shades are seen in separate branches on the same plant, and the clusters of blossoms cover the shrubs in such incredible profusion on the hillsides, that suddenly opening to view from dark shades, we are alarmed with the apprehension of the woods being set on fire. This is certainly the most gay and brilliant flowering shrub yet known."

1. IVy. (Kalmia latifolia, Linn.) - A beautiful shrub known from New England to Georgia, either by the above name, or as Laurel, Mountain Laurel and Calico Bush. In this State it is known under the first and last names, the first being most in use. It is most abundant in the mountains, but is found along streams and on rocky hills of the Middle District, extending somewhat into the Lower, even into the Dismal Swamp. This, in combination with the Laurel, which often accompanies it and blossoms at the same time, presents a scene of floral beauty rarely equaled in this country. Like the Laurel, this is an evergreen, and forms also impenetrable thickets, but its leaves are shining, much darker and smaller. It is 10 to 15 and even 20 feet high. 
The leaves are poisonous to cattle, and a snuff made from them is a powerful sternutatory. An ointment made from the powdered leaves has been successfully used for scald heads. The wood, particularly of the roots, is exceedingly hard, fine-grained, marked with red lines, and capable of a good polish. We have hardly any wood better adapted for the handles of tools, small screws, and similar articles. This and the Laurels can be raised from seeds.

2. WICKY. (K. angustifolia, Linn.) - This has an extensive range over the United States. In this State it is common on the small Pine-barren swamps of the Lower Districts, but is rare in the others. It is 1 to 3 feet high; the leaves are 1 to 2 inches long and $1 / 2$ inch wide, pale green, paler underneath; the flowers roseate or crimson, about $1 / 2$ inch broad, being one-third the size of the preceding, but of the same elegant form, and growing in clusters along the branches. This is a beautiful undershrub and is greatly improved by cultivation. It is a poisonous plant, especially to sheep, and is in some places called Sheep Laurel. A decoction of the leaves is a domestic remedy for cutaneous diseases in man and beast.

3. (K. cuneata, Michx.) - Similar to the Wicky, found in the Lower District, but very rare. It may be distinguished from that by the flowers being white at top and red at bottom, and by the leaves being scattered along the branches, instead of growing in circles of three, as in No. 2.

SAND MYRTLE. (Leiophyllum buxifolium, Ell.) -A small evergreen shrub, 6 to 12 inches high, looking somewhat like the Garden Box, with small, dark green leaves, and small white flowers clustered on the ends of the branches. It grows in sandy woods of Brunswick County, and on the rocky summits of our mountains, from the Grandfather to Whiteside.

FALSE HEATH. (Menziesia globularis, Salisb.) - Common on the higher mountains, 3 to 6 feet high, with thin, hairy, deciduous leaves, and small, reddish, bell-shaped flowers, like those of a Huckleberry, and a small, woody seed-vessel, like those of Andromeda, etc.

1. White Alder. Sweet Pepper-Bush. (Clethra alnifolia, Linn.) - Grows near damp places in the Lower and Middle Districts, 2 to 4 feet high. The leaves are a little like those of the common Alder, but are smaller and narrower. The flowers are small, white, and very fragrant, terminating the branches in racemes which are 2 to 3 inches long. A form of this (var: tomentosa) has leaves with a white down on the underside. 
2. Mountain Pepper-Bush. (C. acuminata, Michx.)-Quite an ornamental shrub, 10 to 15 feet high, growing in the mountains from Ashe to Cherokee. Its leaves are thin, pointed, finetoothed, and 5 to 6 inches long. The racemes of white flowers are larger than in No. 1, and drooping.

(Itea Virginica, Linn.) - At a little distance this has some resemblance to the White Alder, but with a smoother aspect, and the flowers are not fragrant. It belongs to the borders of wet places from the coast to Lincoln, is 4 to 8 feet high, and has small white flowers in drooping racemes, which are 3 to 5 inches long on the ends of the branches.

1. Wild HydrangEA. (Hydrangea arborescens, Linn.)-A smooth shrub, 2 to 5 feet high, growing along streams and on mountain and hill sides of the Upper and Middle Districts. The leaves are 3 to 5 inches long, heart-shaped, pointed, toothed. The flowers are whitish, in flat-topped clusters, some of those on the margin being large and showy like those of, the cultivated $\mathrm{Hy}-$ drangea.

2. SNOWY HYDRANGEA. (H. radiata, Walt.) - Found only on the mountains west of the Blue Ridge from Yancey to Georgia. North of this it has not, I think, been detected. It is from 3 to 6 or 8 feet high. The leaves are heart-shaped, 4 to 6 inches long, the underside clothed with a thick, silvery-white down. The barren flowers, which give this genus the peculiarity for which it is admired, are in this species found only around the border of the flat-topped cluster, but are said to become much more abundant in cultivation. They are of a pure white, an inch or more broad. This pretty shrub would be much prized in gardens, if there were not some more showy species in cultivation.

1. Syringa. (Philadelphus grandiflorus, Wild.)-This very ornamental shrub, now common in our yards and gardens, prized for its graceful, slender branches and snow-white flowers, does not appear to be abundant in this State. I am acquainted with but a single locality of it, which is in Hickory Nut Gap; though it is doubtless to be found along other streams in the upper part of the State. It is 6 to 10 feet high, the leaves about 2 inches long, pointed, with few distant teeth, rather soft and hairy, and tasting somewhat like Cucumbers. The flowers are an inch or more broad.

2. Rough Syringa. (P. hirsutus, Nutt.) - Every way smaller than No. 1, the leaves quite rough on the upper side and whitishdowny beneath. This grows on the French Broad River, a few miles below Asheville. 
1. Mock ORANGE. (Styrax grandifolia, Ait.) - A very beautiful shrub, 3 to 12 feet high, with rather large leaves, 3 to 6 inches long, and of a grayish aspect from the presence of a whitish down on their underside. The flowers are from 15 to 20 on loose nodding racemes, white, very fragrant, in size and form very similar to those of the Orange. It grows on light rich soils in the Lower and Middle Districts, as far west as Lincoln. This is well worthy of a place in shrubberies, but has received but little attention.

2. (S. Americana, Lam.)-Distinguished from No. 1 by its smooth, green leaves, 1 or 2 inches long, and smaller flowers, only 3 or 4 on a raceme. It is 4 to 8 feet high, not inelegant, but of inferior beauty to the other, and grows on the borders of swamps in the Lower District.

1. Bush HoNeysuckle. (Diervilla trifida, Mænch.) -A small, rather delicate shrub, 3 to 5 feet high, with pointed toothed leaves which are 3 or 4 inches long, and have short foot-stalks. The flowers are in clusters of (generally) 3 in the forks of the upper leaves, greenish yellow, and funnel-shaped, like those of the Woodbine. This is found only in the mountains.

2. (D. sessilifolia, Buckley.) -Like the preceding, but larger in several particulars, and the leaves clasp the branches, being destitute of a foot-stalk. Found in the mountains.

1. Strawberry Bush. (Euonymus Americanus, Linn.) - A shrub 2 to 5 feet high, found in all the Districts, and known by the names of Burning Bush, Fish-wood, and Bursting Heart, besides the one first given. The branches are square, straight but flexible, very smooth, and about as green as the leaves. The flowers are small, purplish or greenish, and unattractive. The fruit gives the plant a peculiar beauty, for which chiefly it is prized in shrubberies. This is of a bright crimson color when mature, and covered with small warts which give it somewhat the aspect of a small strawberry. This finally bursts open, exposing its bright scarlet seeds.

2. Burning Bush. (E. atropurpureus, Jacq.)-Every way larger than the preceding, its flowers dark purple, and the fruit smooth. I have not met with it, and am indebted to Prof. Mitchell for my knowledge of it as an inhabitant of this State.

(Stillingia ligustrina, Michx.) - A shrub with slender spreading branches, 6 to 12 feet high, very rare in this State, and not found, I think, north of Cape Fear River. The leaves are 1 to 3 inches long, not toothed, the upper end obtuse, tapering at the lower end, and with a short foot-stalk. For my knowledge of this plant I am under obligations to Dr. McRee. The Tallow Tree 
(S. sebifera), cultivated farther south, and the Queen's Delight (S. sylvatica), an herbaceous plant of the Pine barrens, are members of this genus.

1. (Stuartia Virginica, Cav.) - This and the Loblolly Bay are the only representatives in this country of the admired Camellia family, and the still more important Tea Plant. It is one of our most beautiful shrubs, and yet has nowhere, so far as I know, obtained a popular name. It is found in rich soils in the eastern half of our Lower District, extending north into Lower Virginia, and southward to Florida. It is 6 to 15 feet high, blossoming in April and May. The flowers are white, about the size of the Cherokee Rose, silky on the outer side, covered on the inner with a circle of stamens with bright purple filaments and blue anthers.

2. (S. pentagyna, L'Her.)-Like the preceding, without a name. It is similar to the preceding, only its flowers are creamcolored and its staminate filaments are white. Found in the Middle and Upper Districts, from Wake to Cherokee. The seedvessel in these two is an ovoid woody capsule.

Toothache Tree. (Zanthoxylum Carolinianum, Lam.)Known also by the names of Pellitory and Prickly Ash. The last name, though more legitimate in this application, is generally appropriated in this State to another plant before described. It is a small branching tree, 12 to 20 feet high, the old bark covered with prickles, and peculiar to the southern sea-coast. The bark, leaves, and fruit are aromatic and intensely pungent, producing a rapid secretion of saliva, and are a popular and useful application for toothache. They would probably be generally serviceable as a counter irritant.

1. HARDHACK. (Spiræa tomentosa, Linn.) - An erect branching pretty shrub, 2 or 3 feet high, common in low wet places of the Lower and Middle Districts, and the lower part of the Upper. The leaves are 1 to $11 / 2$ inch long, oblong, coarse-toothed, the under side coated with a rusty-white down. The flowers are rose-colored, small, clustered on the ends of the branches in a compound raceme 3 or 4 inches long.

2. QUEEN OF THE MEADOW. (S. salicifolia, Linn.)-This is similar to No. 1, and sometimes called Meadow Sweet, but is taller and the flowers generally white. The leaves are larger, smoother and thinner. It belongs to damp bushy places in the Middle District, and in valleys and along streams in the lower part of the Upper.

3. Nine BARK. (S. opulifolia, Linn.)-This is found upon river banks in the western part of the State, 6 to 10 feet high, 
with slender curved branches, often spreading like a vine over other shrubs, and covered with a profusion of flat clusters of small, white, but not showy flowers. Leaves about 2 inches long and broad, divided into 3 segments, and coarsely toothed. The reddish fruit is membranaceous, composed of 3 to 5 sacs united at base. The old bark peels off in thin layers.

YELLOW RooT. (Zanthorhiza apiifolia, L'Her.) -A small shrubby plant, 1 or 2 feet high, generally spreading on the ground, found on moist rocky hillsides of the Middle and Upper Districts. The leaves are dark green and divided somewhat like those of Parsley. The flowers are small, dark purple, in loose slender clusters, appearing before the leaves. The roots are intensely bitter, of a yellow color, and were used by the Indians in making a yellow dye.

RED Root. (Ceanothus Americanus, Linn.) -Common in dry woods from the coast to the mountains, 1 to 3 feet high, and the ends of the numerous small branches having loose clusters ( 1 or 2 inches long) of small white flowers supported on white footstalks. The leaves are 1 or 2 inches long, sharply toothed, and have 3 prominent veins. The root is dark red and quite astringent, and is frequently used in infusion, tincture, or powder, where astringency is required. It is said also to furnish a dye of a cinnamon color. The dried leaves served as a substitute for Tea during the Revolution, and hence got the name of New Jersey Tea. It is said to be quite as good as some of the Black Teas.

1. INDIGo BUSH. (Amorpha fruticosa, Linn.) - A very pretty shrub, 6 to 15 feet high, growing upon streams in all the Districts, but more frequent in the Lower. The flowers are small, dark purple, crowded on spikes which are 3 or 4 inches long and clustered together. It is said to have been used for the manufacture of Indigo, but, I imagine, with not much profit.

2. DwARF Indigo Bush. (A. herbacea, Walt.) -Like No. 1 in its whole habit, but only 2 or 3 feet high, of a grayish aspect, and with the flowers whitish or pale-blue. It is frequent in the barrens of the Lower District. The leaves in these two species are pinnate, like those of the Locust and Hickory. The fruit is a very small pod, sprinkled with glands.

He HuCKLEBerRY. (Cyrilla racemiflora, Walt.)-This is an absurd name, but I have never heard any other. This smooth shrub inhabits the borders of swamps and branches in the Lower District, and is 10 to 15 feet high. The leaves are oblong, shining, 2 to 3 inches long. The small white flowers grow on racemes that are 3 to 5 inches long, and that are clustered on the ends of the previous year's growth, and make this quite ornamental. The 
bark at the base of the trunk pulverizes naturally, and is much used as a styptic and in applications to old ulcers.

(Buckleya distichophylla, Torr.) - A smooth shrub, about 6 feet high, with slender grayish branches, known only upon the streams of this State that flow westward, as the Pigeon and French Broad Rivers. Its thin delicate foliage reminds one by its general aspect of the English and Catalonian Jasmine of our gardens. The flowers are greenish and inconspicuous. The fruit is about $1 / 2$ inch long, growing solitary on the end of a branch.

(Darbya umbellulata, Gray.) - Like the preceding, a very rare plant, as yet known only in two or three localities in Georgia, and in the bend of the Catawba, near Lincolnton, in this State. It is 1 to 2 feet high, with opposite branches and leaves, the latter ovate, acute, entire, 1 to 2 inches long, 1 to $11 / 2$ wide, rounded at base, and.with short foot-stalks. The flowers are small, greenish, in a cluster of 3 to 8 , which is borne on a foot-stalk in the forks of the leaves.

Witch HAZEL. (Hamamelis Virginica, Linn.)-Well known by this name through the State. It has the peculiarity of flowering late in the Fall after the leaves have dropped, and maturing its fruit in the following Spring. Its popular name is derived from the use made of its branches in discovering hidden springs of water, minerals, etc. Other kinds, as of the Peach, are indeed sometimes used for this purpose, but I venture to affirm that none in the whole vegetable kingdom are better than those of Witch Hazel.

DWARF ALDER. (Fothergilla alnifolia, Linn.) - Unknown north of Virginia. In this State it is found from the coast to Lincoln. In the Lower District it is 1 to 2 feet high, often but a single unbranched stem, terminated by a tuft of small white flowers before the leaves appear. It grows here upon the borders of Pinebarren swamps, and is rarely much branched. In the Middle District it is found upon rocky hills, is 3 to 5 feet high, forming a branched straggling shrub. The foliage varies a good deal, so that several species have been made of it by some authors; but the leaves are generally not unlike those of Alder. The fruit is a hard capsule, like that of Witch Hazel, and, like that, bursting elastically and expelling the hard bony seeds to a considerable distance.

SweEt Fern. (Comptonia asplenifolia, Ait.) - A small shrubby plant, 1 or 2 feet high, with leaves (3 or 4 inches long) much resembling some of the Ferns, and possessing a grateful aromatic odor like that of the Wax Myrtle. It is found chiefly on rocky 
or gravelly hills of the Upper and Middle Districts, but is occasionally found in dry and sandy woods in the upper part of the Lower. An infusion of this plant is a popular remedy for dysentery.

WAX Myrtle. CANDLE-BERRY MyrtLe. (Myrica cerifera, Linn.) - A well-known shrub with fragrant leaves, common in the Lower District, and found in fruit from 1 to 18 feet in height. The small berry-like nuts, which often hang two or three years on the branches, are covered with a fragrant wax which has been used in the manufacture of soap and candles. The latter burn long and diffuse an agreeable odor. A decoction of the berries has been used for tetters and similar affections. The root is said to be a specific for tooth-ache.

1. Hazel Nut. (Corylus Americana, Walt.) -A shrub 4 to 8 feet high, found in our mountains, and extending north to New England. The nut is much esteemed, but is smaller and harder shelled than the European Hazel or Filbert (C. Avellana).

2. Beaked Hazel Nut. (C. rostrata, Ait.) -Of similar size and range with the preceding; but this has the husk of the fruit prolonged into a beak or horn, and it extends into the Middle District as far down as Orange.

The remaining shrubs are so various in their fruit and general habit, that, to save space, they are here grouped miscellaneously together, most of them being well known by their popular names.

Button Bush. Box. (Cephalanthus occidentalis, Linn.) Common on the borders of streams and swampy grounds in the Lower and Middle Districts, always easily recognized by its round head of small white flowers, which is about an inch in diameter. It is 3 to 4 feet high, and very pretty when in blossom. The inner bark of the roots is an agreeable bitter, and is used for relieving obstinate coughs.

1. Shrubby Trefoll. Hop Tree. (Ptelea trifoliata, Linn.)A shrub 4 to 8 feet high, belonging to the upper part of the Middle District, with trifoliate leaves like those of Clover, the leaflets 2 to 3 inches long, somewhat hairy when young, pale on the underside. The flowers are small, greenish-white, in rather flat clusters, heavy-scented, which are succeeded by flat, winged fruit, like that of the Elm, but an inch broad. The fruit is bitter, and used as a substitute for Hops.

2. Downy HoP Tree. (P. mollis, M. A. C.) - Every way smaller than No. 1, and found only in the Lower District. Its leaves are more rigid, and the underside covered with a permanent, white, soft, silky down. 
Bladder Nut. (Staphylea trifolia, Linn.) - An interesting shrub, 5 to 10 feet high, with greenish, striped branches, trifoliate leaves, the leaflets 2 to 4 inches long, taper-pointed, finely toothed, and smooth. The small white flowers are gathered into loose pendulous clusters, which are succeeded by 3-angled bladder-like pods about two inches long. I have met with this only near Hillsborough and Chapel Hill, but it is probably to be found along streams through the Middle District.

1. Sweet Shrub. (Calycanthus floridus, Linn.) - This plant, now so extensively cultivated, and admired for the rich Strawberry odor of its flowers, is a native of the southern Alleghanies. This species may be known by the soft.down on the underside of the leaves, and on the branchlets, etc. The fruit of this genus is a sort of thick-skinned, bladdery sac, $11 / 2$ inch long, containing large seeds.

2. (C. lævigatus, Willd.) - The léaves of this are taper-pointed, smooth and green on both sides, sometimes a little rough above and pale beneath. This is found in the mountains, and in the Middle District as low down as Orange.

3. (C. glaucus, Willd.) - This is found from Lincoln westward, and may be recognized by the white under-surface of the leaf; a little rough on the upper.

1. Alder. (Alnus serrulata, Ait.) - Common on small streams all over the State, and too well known by the above name to need a description.

2. Mountain Alder. (A. viridis, DC.) - Like the above in habit and general characters, but the underside of the leaves covered with a soft gray down. It is known at the South, only upon the top of Roan Mountain, from whence to northern New York it is not found. It occurs in Europe.

1. Groundsel. (Baccharis halimifolia, Linn.) - Grows in both brackish and fresh swampy grounds of the Lower District. It is 6 to 12 feet high, of an ashy hue from the whitish scales that cover the bark and leaves. The small flower-heads are solitary, or a few clustered together, borne on a foot-stalk. The long, white, silky hairs of the seeds emerging from the heads give the plant a pleasing appearance in the Fall.

2. (B. glomeruliflora, Pers.) - Like the preceding, but rarer and less showy, and has larger clusters of flower-heads, destitute of the foot-stalk.

3. (B. angustifolia, Michx.) - Found in brackish marshes, 4 to 8 feet high. The leaves, which in the other species are half as broad as long, and toothed, are in this linear and entire. 
1. MARSh Elder. (Iva frutescens, Linn.) - A coarse unsightly shrub of our salt marshes, 4 to 6 feet high. The whole plant is smoothish, and its leaves lance-shaped, toothed, and about 2 inches long. The flower-heads are greenish and unsightly in the forks of the small leaves on the terminal branchlets.

2. (I. imbricata, Walt.) - This grows upon the sea-beach, and is but partly shrubby, 3 or 4 feet high. The leaves are very thick and fleshy, 1 to $11 / 2$ inch long, rarely toothed, and wedge-shaped. The plant has a strong odor like old honey.

SWAMP Loosestrife. (Nesæa verticillata, H. B. K.) - A half shrubby plant found in branch swamps of the Lower District, 4 to 6 feet high, with slender, curved, 4 to 6 -sided stems. The leaves are 3 or 4 inches long, narrow like those of a Willow, generally growing around the stem in a circle of three. The flowers are clustered in the forks of the leaves, about $1 / 2$ inch wide, purple or roseate, very pretty, reminding one of the blossoms of the Lagerstræmia or Crape Tree.

ARBor Vitæ. (Thuja occidentalis, Linn.)-This has its southern limit on the mountains in the northwestern part of the State. From thence through the mountains of Virginia it becomes more common. It is but a shrub or small tree at the South, but farther north it attains a height of 50 feet, and its timber is used in building and for cabinet work.

1. CANE. (Arundinaria gigantea, Chapm.) - This belongs to the Grass family, but, being of woody texture, falls within our arrangement. It is 10 to 15 or 20 feet high, found along the river bottoms of the Cape Fear. I am not aware of its existence north of that limit. According to Dr. Chapman, "it is simple the first year, branching the second, afterwards at indefinite periods fruiting, and soon after decaying." The value of the stems for fishing-rods is well known.

2. REED. (A. tecta, Muhl.) - This is the common smaller form, 2 to 10 feet high, and found in low grounds in each District.

This completes the list of the SHRUBS of North Carolina, so far as they are known to me, with the exception of the following, which are too small and obscure to merit more than a bare enumeration.

HYPERICUM. Of this we have five woody species, all with yellow flowers, one of which ( $\mathrm{H}$. prolificum) is occasionally cultivated under the name of Rock Rose.

AsCYRUM. Much like the preceding, also with yellow flowers.

Flowering Moss. (Pyxidanthera barbulata, Michx.) - A very pretty, small, trailing evergreen, with white flowers which ap- 
pear in early Spring, and looking somewhat like a Moss in the absence of blossoms. Belongs to the damp Pine-barrens and Savannas of the Lower District.

HUDSonIA. Only 3 or 4 inches high, also with yellow flowers, of which no locality is anywhere known but on Table Rock, N. C.

Trailing ARbutus, or Ground LAUREL. (Epigæa repens, Linn.) Common.

Polygonella. In the sandy Barrens about Wilmington.

It may be interesting to append here a comparative view of the Flora of North Carolina with that of the Northern and Southern States east of the Mississippi. In Prof. Gray's "Manual of Botany," which includes the States north of North Carolina and Tennessee, I find described 130 Trees, 183 Shrubs, and 30 Vines. In Dr. Chapman's "Flora of the Southern States" are described 126 Trees, (of which there are 112 in North Carolina,) 224 Shrubs, (176 of them in North Carolina,) and 46 Vines (32 in this State). 


\section{THE VINES OF NORTH CAROLINA}

These will be grouped according to the character of their fruit: the first nine genera having Berries; the next five, Pods; the next three, dry Capsules; and the remaining two, naked Feathered Seeds.

GRAPES.-1. SUMMER GRAPE. [Vitis æstivalis, Michx.]Common, as are the other species, excepting the Muscadine, in most parts of the United States. In this State it is found in all the Districts, generally near streams, but sometimes in dry woods, climbing over trees from 30 to 50 feet. The leaves are 4 to 6 inches broad, cut into 3 or 5 divisions, the underside clothed with a reddish, cobweb-like down when young, which mostly falls away in the course of the season. The bunches of fruit are compound, 6 to 8 inches long, the berries $1 / 3$ to $1 / 2$ inch thick, purplish, blackish or bluish, with a bloom; very varying in flavor, frequently very fine.

According to H. W. Ravenel, Esq., of Aiken, South Carolina, who is a good Botanist, as well as a successful cultivator of Grapes, the following cultivated varieties are descended from this species: The Warren, Pauline, Herbemont, Guignard, Clinton, Ohio, Marion, Treveling, Long Grape or Old House, Elsinborough, Seabrook, and Lenoir. With this last he identifies the Black July, Devereux, Thurmond, Sumter, and Lincoln Grapes. I find, however, that there is a difference of opinion in regard to the identity of the Lenoir and Lincoln varieties; some maintaining a perceptible difference, the latter being deemed superior to the other. Dr. C. L. Hunter, of Lincoln, who is paying much attention to Grape culture, especially of our native varieties, pronounces the Lenoir "one of the very best table Grapes," and recommends its general cultivation. He informs me that this, as well as the Warren, came from Georgia.

I learn from the same gentleman that the Lincoln Grape was discovered about the beginning of this century, near the junction of the South Fork and Catawba, by Dr. Wm. McLean, and that he transplanted the whole vine near his house. From this stock Mr. John Hart, of Mecklenburg, derived his, which is still in vigorous existence. From this last, Dr. Butt, of Lincolnton, obtained his cuttings, and sent some of the fruit to Longworth, who gave it the name, now most in use, of the Lincoln Grape, though it was previously known as the Hart Grape, and McLean Grape.

2. Fox Grape. (V. Labrusca, Linn.) - I have met with this only in the Middle District, where it is found in damp thickets, 
running from 15 to 25 or 30 feet. The leaves are roundish, about the same size as those of No. 1, but not so much divided, and covered underneath with a permanent thick down, which is generally white or gray, rarely of a faint rusty hue. The berries are larger than in that, being $1 / 2$ to $3 / 4$. inch in diameter, in small bunches, commonly dark purple, but sometimes amber-colored or whitish, and of various quality, mostly with a musky and rather hard pulp.

The cultivated varieties of this are, according to Mr. Ravenel, the Isabella, Catawba, Bland's Madeira ,Concord, Diana, Rebecca, To Kalon, Anna, Mary Isabel, Ontario, Northern Muscadine, Hartford Prolific, Catawissa, Garrigues, Stetson's Seedling, York Madeira, Hyde's Eliza, Union Village, Early Chocolate, Harvard, Early Black, Green Prolific Kilvington. The first two in the list are, I believe, the most approved, and most extensively cultivated; both of which are said to have originated in this State.

A foreign origin has been claimed for the Isabella, but this is an evident error, proved in the fact that seedlings of the Isabella sometimes revert to our Fox Grape in every particular of leaf and fruit. This has been tested by Mr. Caradeuc, of South Carolina, as I learn from Mr. Ravenel. But what is regarded as a scientific demonstration of its American origin, is the fact that its seedlings sometimes have barren stocks, like all our American species, which is not the case with any European Grapes. Besides, the Isabella, in its specific characters, comes nearer to our Fox Grape than to any other.

Dr. Hunter, who has given much attention to the history of our Grapes, has communicated most of the following items in regard to the Isabella. Dr. Laspeyre was probably its first cultivator in the United States, probably as early as 1805 , as he sold it in the Wilmington Market in 1810. Judge Ruffin cultivated it in Orange County in 1811, under the name of Laspeyre Grape. It is a tradition that Gov. Smith brought it to Smithville in 1809. About the year $1810 \mathrm{Mrs}$. Isabella Gibbs took a rooted cutting from Gov. Smith's garden to Brooklyn, New York, according to a current account. According to Dr. Laspeyre, she got the vine from him. These statements may, in a sort, be reconciled, if Gov. Smith obtained his stock from Dr. Laspeyre. In 1819, Gen. Swift bought the Gibbs place, and it was there the elder Prince first saw and obtained this Grape, which he named the Isabella in compliment to Mrs. Gibbs. Dr. Hunter has some of these statements from Gen. Swift. Dr. Laspeyre was under the impression that this, which he called the Black Cape, was one of the vines which he brought from St. Domingo, but it was probably the accidental introduction of an American among his foreign stocks. Dr. Hunter seems to be of opinion that it came to the 
Cape Fear region from South Carolina, according with the tradition mentioned in Dr. Hawks's History.

The Catawba Grape, as I am informed by Dr. Hunter, originated in Buncombe County on Cain Creek, an affluent of the French Broad. His views on "The Origin of the Catawba Grape" were given last year (1859) in an article for the American Farmer.

3. Muścadine. (V. vulpina, Linn.)-Known also as Bullace, Bull Grape, and Bullet Grape, and farther south as Fox Grape; in Florida, as Mustang Grape. It extends northward as far as Maryland and Kentucky, from whence southward it is one of the most common vines. In this State it is found, in various soils, from the coast to Cherokee, but most luxuriant in light soils of the Lower District, covering the loftiest trees. The bark is pale and smooth, that of the smaller branches dotted with minute warts. The leaves are about 3 inches long, thin, smooth and shining, coarse-toothed, and nearly round and heart-shaped. The berries are in small bunches, larger and thicker skinned than any of our other Grapes, varying in color from whitish through different shades of red and purple to ebony black. The quality of the fruit varies as much as its color, being now of a sharp acid flavor, and again of luscious sweetness.

The Scuppernong, now so famous as a Table and Wine Grape, is a variety of this species. There are still found in the Lower and Middle Districts, especially in the former, wild vines bearing a whitish or amber berry, like the original Scuppernong, but of various qualities, as in the case with the colored kinds. Some of them are no better than the commonest Muscadines; and no one is superior, if equal, to the well known cultivated variety. Some of the dark Muscadines are very nearly as luscious as the Scuppernong, and have been brought under culture, as the Mish Grape, and Alexander's Grape, which are black, and also the Bull's Eye, so named from its superior size.

The Hickman Grape I take to be identical with the true Scuppernong and derived from Tyrrell County, the home of the original. For some of this information, as well as for the following history of the Scuppernong (proper), I am indebted to Rev. E. M. Forbes, who has resided in the region and has taken much pains to obtain an authentic account of this vine. Two men, of the name of Alexander, while clearing land near Columbia, the county seat of Tyrrell, which stands on the east side of Scuppernong River, discovered this Grape, and were so much pleased with it that they preserved the vine and the tree upon which it grew. "That was the vine which I saw," says Mr. Forbes, "and from which other vines were propagated." They 
called it the "White Grape," and from it made what they called "Country Wine." At the suggestion of a relative, who had been in the Mediterranean, and knew the indefiniteness of such names as these, they subsequently named the Grape from the river upon which it was found. "This is the history given by a granddaughter of one of the discoverers, who was alive when I first went to Scuppernong."

A tradition is furnished me by Dr. Hunter, that, "about the year 1774, the Rev. Charles Pettigrew found it on the low grounds of Scuppernong River, and planted out several vines." My limited space will not permit an exhaustive discussion of this matter here, and I will, therefore, only remark further upon it, that the notion of its origination on Roanoke Island seems opposed by the name of the Grape. I have also been told by those who have been on the Island, that there are no vines of it there which were not evidently transplanted there.

4. Frost Grape. Winter Grape. (V. cordifolia, Michx.) Common in thickets along streams through the Middle District. The leaves are 3 to 5 inches broad, thin, smooth, toothed, and sometimes cut into three segments. The berries are nearly black, small, $1 / 4$ inch thick, and very sour until dead ripe. The berries are sometimes greenish-white, and Lawson mentions a white [whitish?] variety. I have not heard of this being cultivated.

5. (V. bipinnata, Torr. \& Gr.) - This would not generally be taken for a member of this genus, either from its leaves, which are compound, like those of the China Tree, or from its fruit, which is uneatable. The berries are blackish, slightly hairy, and about the size of a small pea. It is found in the Lower and Middle Districts, growing in rich soils, climbing (without tendrils) over shrubs and small trees.

VIRGINIA CREEPER. (Ampelopsis quinquefolia, Michx.)-This pretty vine, sometimes cultivated, is found along fence-rows and borders of woods in all parts of the State. It may be known by its leaflets growing in fives from the end of a common leafstalk, as in the Buckeye, which is the case with no other of our Climbers. The foliage becomes crimson in the Fall. The berries are dark-blue, about the size of a small pea, borne on bright crimson foot-stalks. The rapidity of its growth renders this Creeper useful for covering old walls, etc., like the English Ivy. It is, indeed, sometimes called American Ivy. This is often confounded with the Poison Vine, though having very little likeness to it, and is hence avoided, though it be quite innocent.

1. Woodbine. (Lonicera sempervirens, Ait.) - This beautiful vine, now common in cultivation, grows from the coast to the 
mountains. The flowers are tubular, 1 to 2 inches long, scarlet without and yellow within. In rich soils it has a very luxuriant growth, climbing high into forest trees.

2. Yellow Woodbine. (L. grata, Ait.) - This belongs to the mountains, and has a flower 1 to $11 / 2$ inch long, reddish on the tubular part, whitish at top, then changing to yellow, somewhat fragrant. The young branches are often hairy.

3. SMALL Woodbine. (L. parviflora, Linn.) - Found in the mountains, less climbing than the others, with flowers about $2 / 3$ inch long, somewhat swollen at the base of the tube, and greenishyellow tinged with purple.

I have heard of a yellow species in Gates County, but have never seen any specimens.

1. COMMON BAMBOo OR GREeN BRIER. (Smilax rotundifolia, Linn.) - Very common in all the Districts, generally in thickets where the soil is rather fertile, 20 to 40 feet long, the stems and branches of a yellowish-green color, round, and armed with strong prickles, the branchlets slightly angled. The leaves are deciduous, 3 or 4 inches long, roundish and heart-shaped. The berries, as in most of the species, are bluish-black, borne in bunches upon a common stalk in the fork of the leaves, and which is about the same length with the leaf-stalk.

2. (S. tamnoides, Linn.) - A stout prickly vine with angled branchlets, occurring in the Lower and Middle Districts. The leaves are somewhat fiddle-shaped or contracted in the middle, the base sometimes spreading into rounded projections. The general fruit-stalk is a little flattened, about $11 / 2$ inch long, and twice the length of the leaf-stalk.

3. China Root. (S. Pseudo-China, Linn.) - Stout and prickly like No. 2, 10 to 15 feet long, the branches roundish and not prickly, and the roots tuberous. The leaves are large, 4 to 7 inches long, ovate, green both sides, the edges and nerves on the underside roughened with minute prickles. The general fruitstalk is flat and 2 or 3 inches long. The berries are blackish and larger than in the preceding species.

4. SARSAPARILla. (S. glauca, Walt.)-Not uncommon in all the Districts in cultivated grounds near streams. The stems are prickly and 2 to 4 feet long. The leaves are ovate, and covered, especially on the underside, with a white bloom that rubs off under the finger. The berries are black. The common fruitstalk is 2 or 3 times longer than the leaf-stalk. The root of this is sometimes used in the composition of diet drinks. It is not the Sarsaparilla of the druggists, but is said to be often mixed with it. 
5. (S. Walteri, Pursh.) - Stem dark green, angled, 10 to 15 feet long, having prickles only towards the bottom, running over bushes and up small trees in branch swamps of the Lower District. Leaves decïduous, ovate, heart-shaped, smooth, dark shining green above, paler beneath, terminating in a small, almost prickly point, 3 to 4 inches long, 2 to 3 wide, and having 3 distinct and 2 obscure nerves. The berries are scarlet and very conspicuous in Winter. This has a creeping root.

6. (S. lanceolata, Linn.) - This and No. 5 are the only species with red berries. But this has evergreen leaves, narrower than in the preceding and acute at base. The branches, too, are not angled, and the root is tuberous. I have not myself met with it, and give it on the authority of others.

7. (S. laurifolia, Linn.) - This is a showy species, and like Nos. 6 and 8, has evergreen leaves. It runs to a great length over bushes and up lofty trees, the lower part only being prickly. The leaves are thick and shining, lance-shaped or oblong. The general fruit-stalk is equal to the leaf-stalk, $1 / 6$ to $1 / 4$ inch long. Berries black. This seems confined to wet places in the Lower District.

8. (S. auriculata, Walt.) - Similar to No. 7, slightly or not at all prickly, growing over small shrubs on the coast, flowers fragrant. The leaves are perennial, 1 to 2 inches long, narrowly ovate, 3 to 5 nerved, with conspicuous cross veins, especially beneath, terminated by an abrupt almost prickly point. Common fruit-stalk rather shorter than the leaf-stem. Berries black.

RAtTAN. SuPPle JACK. (Berchemia volubilis, DC.) - A very tough flexible vine running up trees. The leaves are alternate, 1 to 2 inches long, ovate, dark green, very smooth, not toothed, having prominent parallel unbranched straight veins running obliquely from the midrib to the margin. The berry is dark purple, about $1 / 4$ inch long, with a thin coat and a hard smooth nut. Grows from Virginia southward through our Lower District.

(Sageretia Michauxii, Brogn.) - Grows upon the sandy soil of the coast, 6 to 18 feet long, with thorn-like spreading branches. Leaves 1 inch long, ovate, opposite, smooth and shining, finely toothed. Flowers very small, in loose clusters. The berry is small and round, dark purple, and pleasantly acid. I have not met with this, and have introduced it here on the authority of Michaux.

(Cocculus Carolinus, DC.) - This runs extensively over shrubs and small trees on the borders of damp woods and streams, from the coast to Lincoln. The leaves are 2 to 4 inches long, broadly 
ovate and heart-shaped, sometimes 3 lobed, smooth above, with a soft gray down underneath. The ripe berries are red, about the size of a small pea, growing in small clusters, containing a hard flat nut which is curved nearly into a ring.

Moon SEED. (Menispermum Canadense, Linn.) - This is 6 to 12 feet long, and woody only in the lower part. It is the only one of our woody Climbers that has the leaf-stalk inserted into the plate of the leaf instead of the lower edge. The berries are black and contain a flat nut, as in the preceding species, curved into the form of a horse shoe. Rare in the Lower District, not uncommon elsewhere.

PoISON VINE. (Rhus radicans, Linn.) - Now considered by Botanists as only a variety of Poison Oak, but necessarily separated in the arrangement $I$ have adopted. It is the only trifoliate woody Climber we have. Like Poison Oak and Poison Sumach, very poisonous to some people. Common throughout the State.

The next GRouP of ClIMBERS, comprising five genera, have their fruit in dry pods. All of the species are ornamental.

TRUMPET FLOWER. (Tecoma radicans, Juss.) - This splendid Climber, ascending the loftiest tree, is found from the coast to the lower part of the mountains, preferring damp rich soils. Its dark green compound leaves, and scarlet tubular flowers which are 2 to 3 inches long, make it an attractive ornament in yards and gardens. This harmless plant has the reputation, with some, of being poisonous.

CRoss VINE. (Bignonia capreolata, Linn.) - This, like the preceding, is sometimes called Trumpet Flower. The flowers are of similar form, about 2 inches long, but are of a duller red on the outside and yellow within. The leaves are of a dull green, growing in pairs from the end of a common foot-stalk, each leaflet also having its own stalk. This does not climb to so great a height as the other. A cross section of the stem exhibits a portion of its inner structure in the form of a Maltese cross, which gives the name to this plant. Not uncommon in the Lower and Middle Districts.

VIRGIN's Bower. (Wistaria frutescens, DC.) - This luxuriant, much admired Climber is found, I think, only in damp rich soils of the Lower District. It stands cultivation remarkably well in the Middle District. The leaves are pinnate, like those of the Locust; and the flowers are of the size and structure of the Garden Pea, purplish-blue, in large pendent compact clusters 4 to 6 inches long. We have no other woody Vine answering to these characters. The stem is exceedingly tough and serves well for withes or ligatures. 
Carolina Jessamine. (Gelsemium sempervirens, Ait.)-No plant is more common in the Lower District, but it reaches very little into the Middle. It extends northward into Virginia, but becomes much more luxuriant as we go south. Its graceful evergreen leaves, the profusion of its large, bright yellow and deliciously fragrant blossoms, render this vine the pride of our forest. The odor of the flowers in a close room sometimes induces headache. Most of the plant, especially the root, taken internally, is narcotic and poisonous. A tincture of the root, judiciously administered, is useful in rheumatic affections; but in the hands of quacks death has been caused by it.

(Forsteronia difformis, A. DC.) - A smooth twining plant, 6 to 12 feet long, found chiefly in the Lower District, but extending into the interior as far at least as Wake County. It is sometimes mistaken for the Yellow Jessamine, but the flowers are tubular and smaller, more like those of a Woodbine, about 1-3 inch long, and greenish-yellow. The fruit is a slender pod, containing seeds that have a tuft of down.

The next GRoup of three genera have their seeds in small dry capsules.

WAX-WORK. BitTersweET. (Celastrus scandens, Linn.) - This is to me the rarest plant in the State, as I have seen but a single stock, near Lincolnton. This is its most southern known limit. It ascends trees to the height of 12 or 15 feet. The leaves are about 3 inches long, taper pointed, smooth, toothed. The berrylike capsule is orange-red, clustered on the ends of its short branches, of the size of a large pea, bursting when mature and disclosing 3 to 6 scarlet seeds. In this state it is quite an ornamental vine.

(Decumaria barbara, Linn.) - A pretty vine ascending trunks by means of rootlets insinuated into the bark, after the manner of the Poison Vine. The leaves are 3 to 4 inches long, broadly ovate, opposite, rather thick and shining, generally with scattered teeth towards the upper end. The flowers are small, white and fragrant, in showy compound clusters on the ends of the branches, opening in May. This is found in the Lower District only, and is unknown north of this State.

Wild Ginger. Big SARsaparilla. (Aristolochia Sipho, L'Her.) - Found in rich soils all along our mountain rivulets, climbing over bushes, and sometimes ascending trees. The stems are occasionally 2 inches thick. The leaves are roundish, heart-shaped, 8 to 12 inches broad, and slightly downy on the underside. The flower is coarse, brownish-purple, 11/2 inch long, somewhat tubular, with top cut into three segments, below which 
it is contracted and curved like a Dutch pipe, from which, in some parts of the United States, it has gotten the name of Dutchman's Pipe. The root is very aromatic and stimulant, like Ginger, and would serve as a medicine where these properties are indicated.

The two remaining genera have naked seeds, which are remarkable for their long feathered tails.

VIRGIN'S BowER. (Clematis Virginiana, Linn.) - A partly woody vine, 10 to 15 feet long, climbing over thickets and fences. It is found from the coast to the mountains, generally near streams, but is less common in the Lower District. The leaves are composed of 3 ovate leaflets which are a little cut. The flowers are in loose clusters, $1 / 2$ to $3 / 4$ inch broad, and clothing the upper part of the vine with a flowing mantle of white. The flowers are succeeded by heads of feathered seeds which are still more ornamental than the blossoms.

(Atragene Americana, Sims.) - This is accredited by others to the mountains of North Carolina, but it has escaped my own observation. It is a very showy vine, both in fruit and flower, and, like the preceding, is woody only in its lower parts. It climbs over rocks and bushes by means of its leaf-stalks. The leaves are in pairs on opposite sides of the stem, making 4 in a circle, each long leaf-stalk bearing 3 leaffets. The flowers are bluish-purple, 2 to 3 inches broad, followed by heads of seeds which have long feathered tails. 
STATE LIBRARY OF NORTH CAROLINA

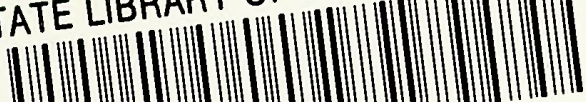

3 3091006575716

\section{DATE DUE}

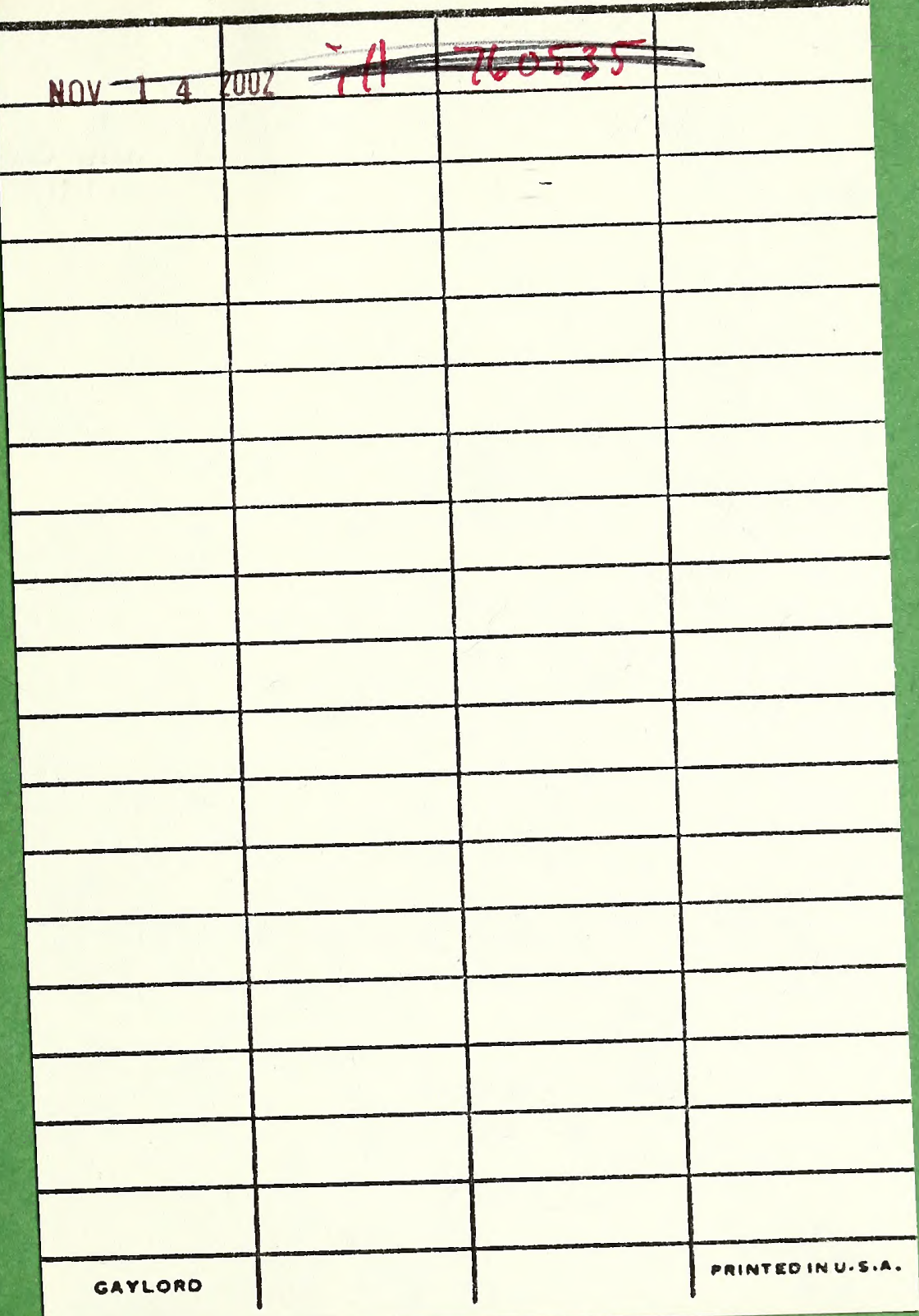


